Geological Society of America

Special Paper 418

2007

\title{
Genesis of the Neogene to Quaternary volcanism in the Carpathian- Pannonian region: Role of subduction, extension, and mantle plume
}

\author{
Szabolcs Harangi* \\ Department of Petrology and Geochemistry, Eötvös University, H-1117 Budapest, Pázmány Péter sétány 1/C, Hungary \\ László Lenkey \\ Hungarian Academy of Sciences, Research Group of Geophysics and Environmental Physics, \\ 1117 Bp., Pázmány Péter sétány 1/C, Hungary
}

\begin{abstract}
Neogene to Quaternary volcanism of the Carpathian-Pannonian region is part of the extensive volcanic activity in the Mediterranean and surrounding regions. Using the spatial and temporal distribution of the magmatic rocks, their major- and traceelement features, and $\mathrm{Sr}-\mathrm{Nd}-\mathrm{Pb}$ isotope characteristics, we suggest that lithospheric extension in the Pannonian Basin had a major role in the generation of the magmas. Dehydration of subducting slab should have resulted in thorough metasomatism in the mantle wedge during Cretaceous to early Miocene that would have lowered the melting temperature, therefore playing an indirect role in the generation of magmas later on. Mixing between mantle-derived magmas and lower-crustal melts was an important process at the first stage of the silicic and calc-alkaline magmatism in the Northern Pannonian Basin. However, the crustal component gradually decreased with time, which is consistent with magmatic activity in a continuously thinning continental plate. Calc-alkaline volcanism along the Eastern Carpathians was mostly postcollisional and could have been related to slab break-off processes. However, the fairly young ( $<1.5 \mathrm{Ma}$ ) potassic magmatism at the southeasternmost segment of the Carpathian volcanic arc could be explained by lithospheric delamination under the Vrancea zone. Alkaline basaltic volcanism began at the end of rifting of the Pannonian Basin (11 Ma) and continued until recently. We suggest that a mantle plume beneath the Pannonian Basin is highly unlikely and the mafic magmas were formed by small degree partial melting in a heterogeneous asthenospheric mantle, which has been close to the solidus temperature due to the lithospheric extension in the Miocene. Magmatism appears to have been in a waning phase for the last 2 m.y., but recent volcanic eruptions ( $<200$ k.y.) indicate that future volcanic activity cannot be unambiguously ruled out.
\end{abstract} region.

Keywords: petrogenesis, subduction, extension, mantle plume, Carpathian-Pannonian

\footnotetext{
*E-mail: szabolcs.harangi@geology.elte.hu.

Harangi, S., and Lenkey, L., 2007, Genesis of the Neogene to Quaternary volcanism in the Carpathian-Pannonian region: Role of subduction, extension, and mantle plume, in Beccaluva, L., Bianchini, G., and Wilson, M., eds., Cenozoic Volcanism in the Mediterranean Area: Geological Society of America Special Paper 418, p. 67-92, doi: 10.1130/2007.2418(04). For permission to copy, contact editing@geosociety.org. @2007 Geological Society of America. All rights reserved.
} 


\section{INTRODUCTION}

Widespread magmatism developed in the Mediterranean and surrounding regions during the Neogene to Quaternary (Wilson and Downes, 1991; Wilson and Bianchini, 1999; Lustrino, 2000; Wilson and Patterson, 2001; Harangi et al., 2006). A large variation of magmatic rocks was produced that can be roughly divided into orogenic (calc-alkaline, potassic, and ultrapotassic) and anorogenic (alkaline sodic) types. At the periphery of the Mediterranean region, mostly alkaline mafic rocks occur, with minor amounts of differentiated rocks, whereas within the Mediterranean region, calc-alkaline and potassic-ultrapotassic rocks predominate, with sporadic tholeiitic and alkaline sodic rocks. Interpretations of the origin of this wide range of magmas are usually controversial and they involve contrasting tectonic processes, such as subduction, subducted slab detachment, or slab break-off, lithospheric extension, and mantle plume upwelling (Wilson and Bianchini, 1999; Peccerillo, 2005; Harangi et al., 2006).

Volcanism is still active in the Central Mediterranean, whereas in the other areas, the last volcanic eruptions took place within a few tens or hundreds of thousands of years. In order to evaluate the possible renewal of volcanic activity of these latter areas, it is crucial to identify the tectonic controls on magmatism, i.e., the cause of melt generation. The relative roles of plate tectonic processes (subduction or extension) versus deep mantle processes (i.e., mantle plume upwelling) in melt generation are still unclear.

The Carpathian-Pannonian region is considered to be a typical Mediterranean area characterized by arcuate, retreating subduction, formation of extensional basins within the orogen, and a wide range of erupted magmas in the last 20 m.y. (Horváth and Berckhemer, 1982; Csontos et al., 1992; Szabó et al., 1992; Lexa and Konečný, 1998; Kovač et al., 1998; Seghedi et al., 1998, 2004a, 2005; Fodor et al., 1999; Tari et al., 1999; Harangi, 2001a; Konečný et al., 2002). On the other hand, it shows many similarities with the circum-Mediterranean alkaline mafic volcanic fields (Wilson and Downes, 1991; Embey-Isztin et al., 1993), and, thus, a mantle plume finger has been supposed by some authors to exist beneath the Pannonian Basin (Embey-Isztin and Dobosi, 1995; Wilson and Patterson, 2001; Seghedi et al., 2004b). In this paper, we discuss the origin of the Neogene to Quaternary magmatism in the Carpathian-Pannonian region, especially melt generation processes and the possible role of subduction, lithospheric extension, and mantle plume processes.

\section{GEODYNAMIC SETTING}

The Carpathian-Pannonian region is located in the northeastern part of the Alpine-Mediterranean region (Fig. 1), in eastern Central Europe, and is characterized by an arcuate orogenic belt (Carpathians) with a basin area behind it (the Pannonian Basin) that has thin lithosphere (50-80 km) and crust (22-30 km) coupled with high heat flow $\left(>80 \mathrm{~mW} / \mathrm{m}^{2}\right.$; Csontos et al., 1992; Fodor et al., 1999; Tari et al., 1999; Bada and Horváth, 2001;
Lenkey et al., 2002). The intra-Carpathian region is composed of two major crustal blocks (or microplates; Fig. 2A): the North Pannonian block (or Alcapa) to the north and the Tisza block (or Tisia-Dacia) in the south (Balla, 1986; Csontos et al., 1992).

Following the Eocene continent-continent collision in the Alpine region, S-SW-dipping subduction continued in the east (Carpathian subduction zone) during the Neogene, where an oceanic embayment was present (Csontos et al., 1992; Nemčok et al., 1998; Fodor et al., 1999). This weak lateral boundary could have enabled the eastward lateral extrusion of a crustal block (North Pannonian block; Balla, 1988) from the compressive Alpine regime during the early Miocene (Ratschbacher et al., 1991). The eastward translation was accompanied by two major counterclockwise rotational events at 18-17 Ma and 16-14.5 Ma (Márton and Fodor, 2003). Contemporaneously, the Tisza block underwent opposite-sense rotation (Patrascu et al., 1990, 1994; Csontos, 1995).

The advancing subduction style changed to a retreating one during the early Miocene (Royden, 1993). Retreat of the subduction zone beneath the Carpathians is considered to have been the main driving force for the lateral movement of the North Pannonian block toward the northeast. Behind the subduction zone, backarc extension occurred in the whole Pannonian area during the middle Miocene (Royden et al., 1982; Horváth, 1993). In addition, Tari et al. (1999) defined an initial core-complex style extension during the early Miocene. Huismans et al. (2001) distinguished two main rifting events: a middle Miocene passive rifting followed by a late Miocene active rifting event. The synrift phase (17-12 Ma; Horváth, 1995) was followed by postrift thermal subsidence, when several thousands of meters of late Miocene to Quaternary sediments filled parts of the basin areas.

At the northern boundary of the region, "soft" collision (Sperner et al., 2002) of the North Pannonian block with the European continent occurred during the Badenian (ca. 1315 Ma; Jiř́íček, 1979), whereas subduction was still active along the East Carpathians. Active subduction ceased beneath the East Carpathians during the late Miocene (ca. 10-11 Ma), which was then followed by continental collision. Postcollisional slab break-off is considered to have occurred gradually from west to east-southeast in a zipper-like process (Tomek and Hall, 1993; Mason et al., 1998; Seghedi et al., 1998; Wortel and Spakman, 2000; Sperner et al., 2002). Slab break-off is now thought to be in its final stages beneath the southern part of the Eastern Carpathians (Vrancea zone Fig. 2B), where a near-vertical subducted slab causes intermediate depth seismicity (Oncescu et al., 1984; Oncescu and Bonjer, 1997; Sperner et al., 2001). Seismic tomographic and gravity modeling indicate that this slab is still hanging (Fan et al., 1998; Wenzel et al., 1998, 2002; Sperner et al., 2001, 2004). The present-day situation has been explained by various models involving subduction break-off (e.g., Mason et al., 1998), subduction rollback followed by horizontal lithospheric delamination (e.g., Doglioni, 1993; Gîrbacea and Frisch, 1998; Gvirtzman, 2002), and active continental lithospheric delamination without subduction (e.g., Knapp et al., 2005). 


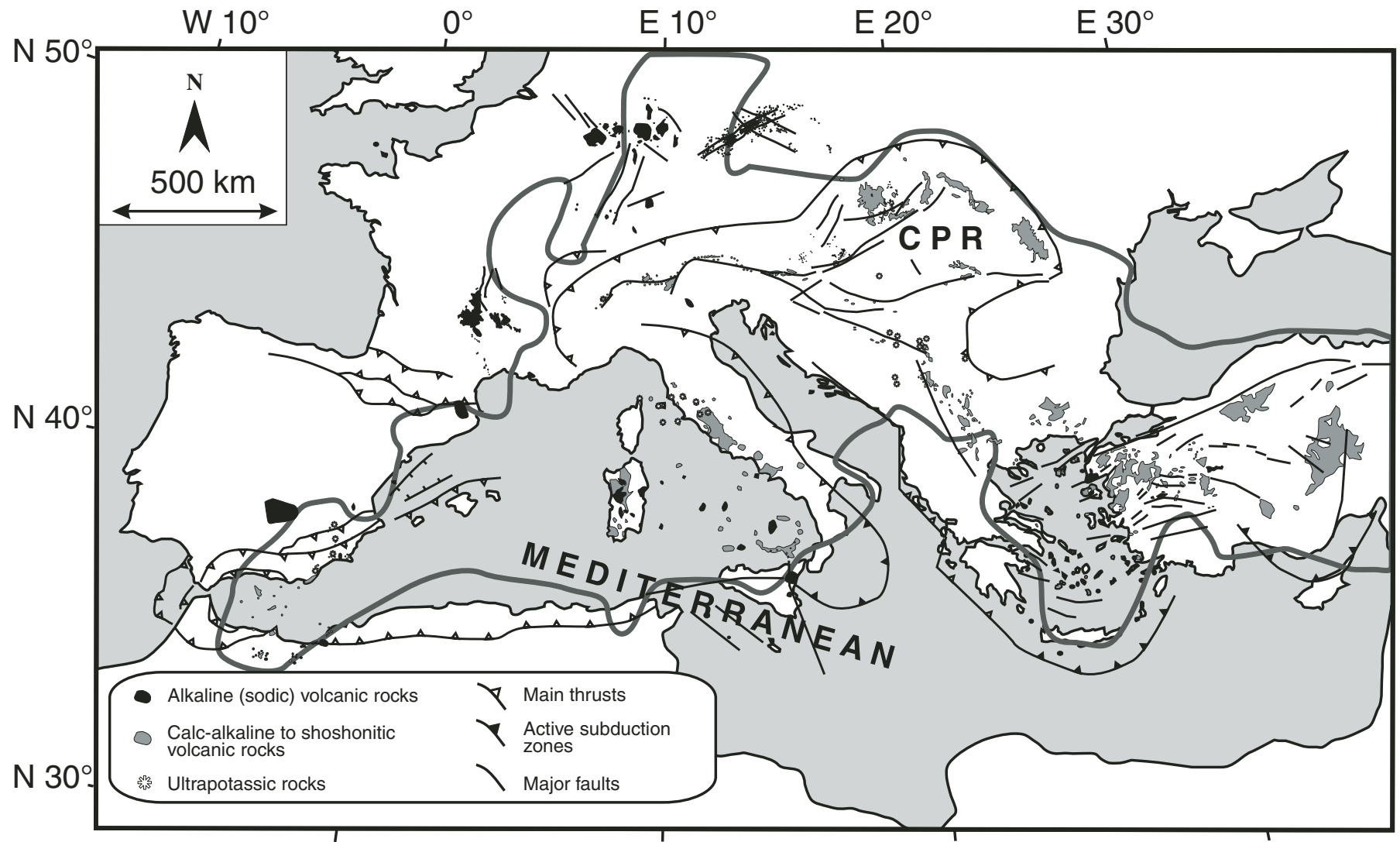

Figure 1. Simplified map for the distribution of Tertiary to Quaternary volcanic rocks in central and southern Europe and the location of the Carpathian-Pannonian region (CPR). The thick line delineates the area underlain by high seismic velocity at the transitional zone, based on Piromallo and Morelli (2003).

Tectonic inversion has characterized the Pannonian Basin since the late Pliocene due to the push of the Adriatic plate from southwest and blocking by the East European platform in the east (Horváth and Cloething, 1996).

This complex geodynamic evolution was accompanied by the formation of a wide range of magmatic rock types over the last 20 m.y. (Figs. 2A and 3; Szabó et al., 1992; Lexa and Konečný, 1998; Harangi, 2001a; Seghedi et al., 2004a). The volcanic rocks can be divided into the following main groups based on their geochemistry (Harangi, 2001a): (1) Miocene (21-13 Ma) silicic pyroclastic (mostly ignimbrite) suite; (2) middle Miocene to Quaternary (16.5-2 Ma) calc-alkaline volcanic rocks; (3) Miocene to Quaternary (15-0.02 Ma) potassic and ultrapotassic rocks; and (4) late Miocene to Quaternary (11-0.2 Ma) alkaline sodic volcanic rocks. Note that this division is slightly different from that of Seghedi et al. (2004a), who considered the silicic volcanic suite to be part of the calc-alkaline group. In our grouping, we separate the silicic volcanic suite because these rocks consist predominantly of $\mathrm{SiO}_{2}$-rich $(>70 \mathrm{wt} \%$ ) pumices (with only a minor amount of andesitic lithic clasts) and they do not overlap spatially with the typical calc-alkaline stratovolcanic complexes. These silicic volcanic rocks have a transitional peraluminous to metaluminous character (Harangi et al., 2005).

\section{GEOCHEMICAL CHARACTERISTICS}

Detailed summaries of the geochemical features of the Neogene to Quaternary volcanic rocks of the Carpathian-Pannonian region can be found in Harangi (2001a) and Seghedi et al. (2004a, 2004b, 2005). Here, we outline only the most important characteristics. Tables 1 and 2 show representative chemical composition of various volcanic rocks of the CarpathianPannonian region.

\section{Major- and Trace-Element Data}

The major-element composition of the Neogene to Quaternary volcanic rocks from the Carpathian-Pannonian region shows a wide variation in the $\mathrm{SiO}_{2}$ versus $\mathrm{Na}_{2} \mathrm{O}+\mathrm{K}_{2} \mathrm{O}$ diagram (Fig. 4). The Miocene Si-rich suite includes only pyroclastic rocks (ignimbrite and less pyroclastic fall deposits) and has a bimodal composition with a gap at $66-70 \mathrm{wt} \% \mathrm{SiO}_{2}$. The pumices are exclusively rhyolites, whereas the cognate lithic clasts and the subordinate scoriae have a basaltic andesitic to rhyolitic composition. This compositional variation overlaps that of the Miocene to Quaternary calc-alkaline suite (Fig. 4). In the calcalkaline volcanic series, andesites and dacites dominate, with 


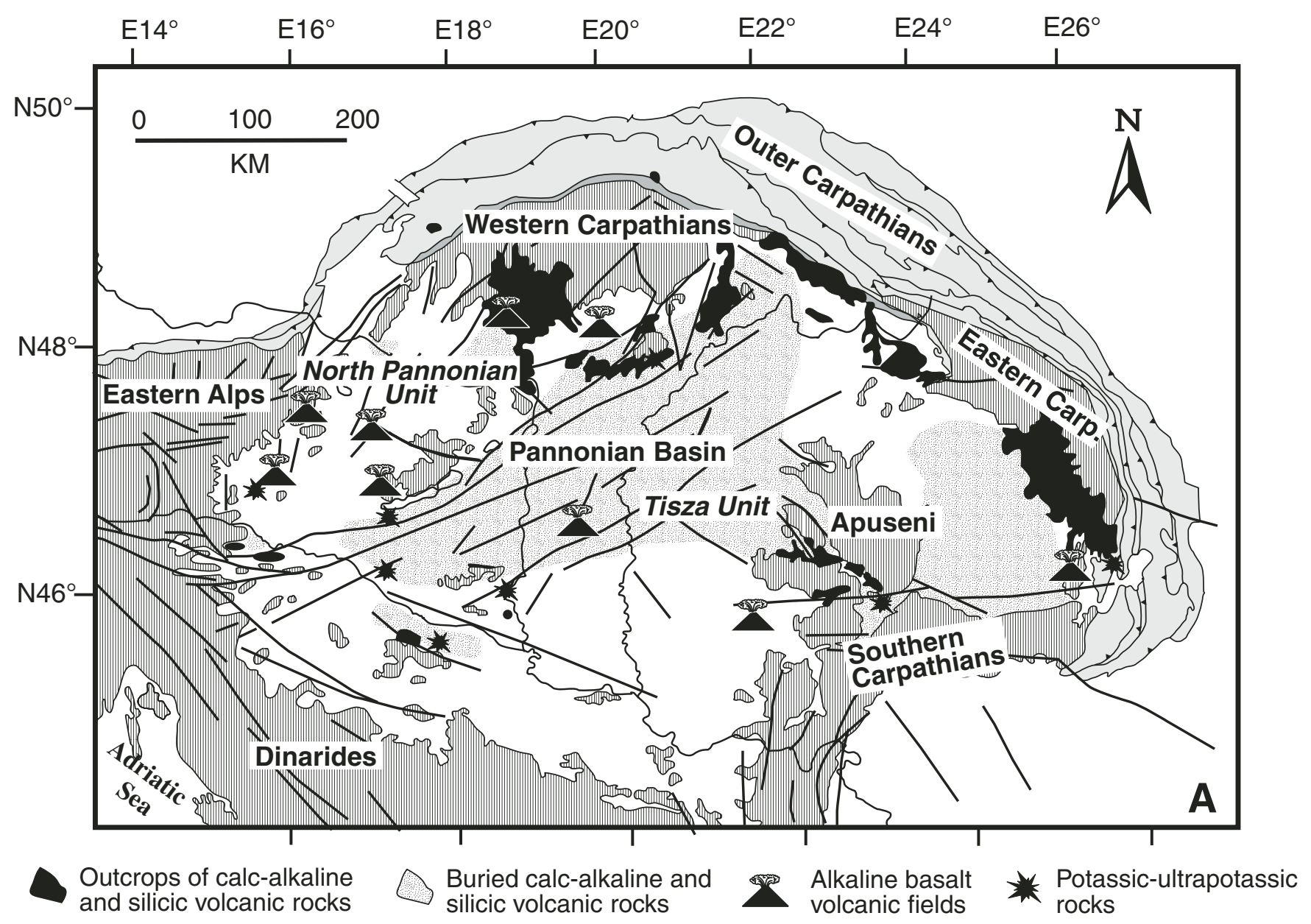

Figure 2 (on this and following page). (A) Distribution of the Neogene to Quaternary volcanic rocks in the Carpathian-Pannonian region.

lesser amounts of basalts, basaltic andesites, and rhyolites. The calc-alkaline mafic rocks $\left(\mathrm{SiO}_{2}=49-57 \mathrm{wt} \% ; \mathrm{MgO}>3 \mathrm{wt} \%\right)$ have Mg-numbers $\left(=\mathrm{Mg} / \mathrm{Mg}+\mathrm{Fe}^{2+}\right)$ of $0.5-0.6$, suggesting variable degrees of crystal fractionation. Slight compositional differences can be recognized between the western and eastern segments of the Carpathian volcanic chain. The calc-alkaline volcanic suites from the western segment belong mostly to the high-K series, whereas those from the eastern segment show a larger variation in the $\mathrm{K}_{2} \mathrm{O}$ content (from low- $\mathrm{K}$ tholeiites to shoshonites; Mason et al., 1996). The sporadic potassic and ultrapotassic rocks are mostly silica-saturated shoshonites and high-K dacites, whereas there is only a single silica-undersaturated occurrence in the Carpathian-Pannonian region, an olivineleucitite in the southern Pannonian Basin (Bár; Fig. 2B herein; Harangi et al., 1995b; recently another leucitite occurrence has been recognized from the southern Pannonian Basin, Seghedi, 2005, personal commun.). The olivine-leucitite has a Mg-number of 0.7 , suggesting a near-primitive composition, whereas the others underwent variable olivine + clinopyroxene fractionation. The last volcanic eruption in the Carpathian-Pannonian region
(St. Anna eruption in the Ciomadul volcano of the southeast Carpathians at 10-30 ka; Szakács et al., 1993) produced high-K dacite pumices. This was preceded by lava dome eruptions with the same magma composition from $0.9 \mathrm{Ma}$ to $0.5 \mathrm{Ma}$ and by the formation of shoshonitic bodies at 1.5 Ma (Mason et al., 1996). We classified both rock types into the potassic group. The late Miocene to Quaternary alkaline suite consists mostly of mafic rocks (nephelinites, basanites, alkali basalts, and trachybasalts; Embey-Isztin et al., 1993; Seghedi et al., 2004b). However, a thick, 11-12 Ma trachyandesite to alkaline trachyte volcanic complex with minor alkali basalts has been found in the Little Hungarian Plain (Fig. 2B), eastern Pannonian Basin, beneath 2000-m-thick sediments (Harangi et al., 1995a; Harangi, 2001b). The Mg-number of the mafic rocks varies between 0.56 and 0.76 , but it is mostly between 0.63 and 0.68 . This suggests that most of them underwent only minor olivine and \pm clinopyroxene fractionation, and compositions of the basaltic rocks are close to the primary magmas. Mantle-derived ultramafic and lower-crustal granulite xenoliths are common in these rocks (Embey-Isztin et al., 2003; Szabó et al., 2004, and references therein). 


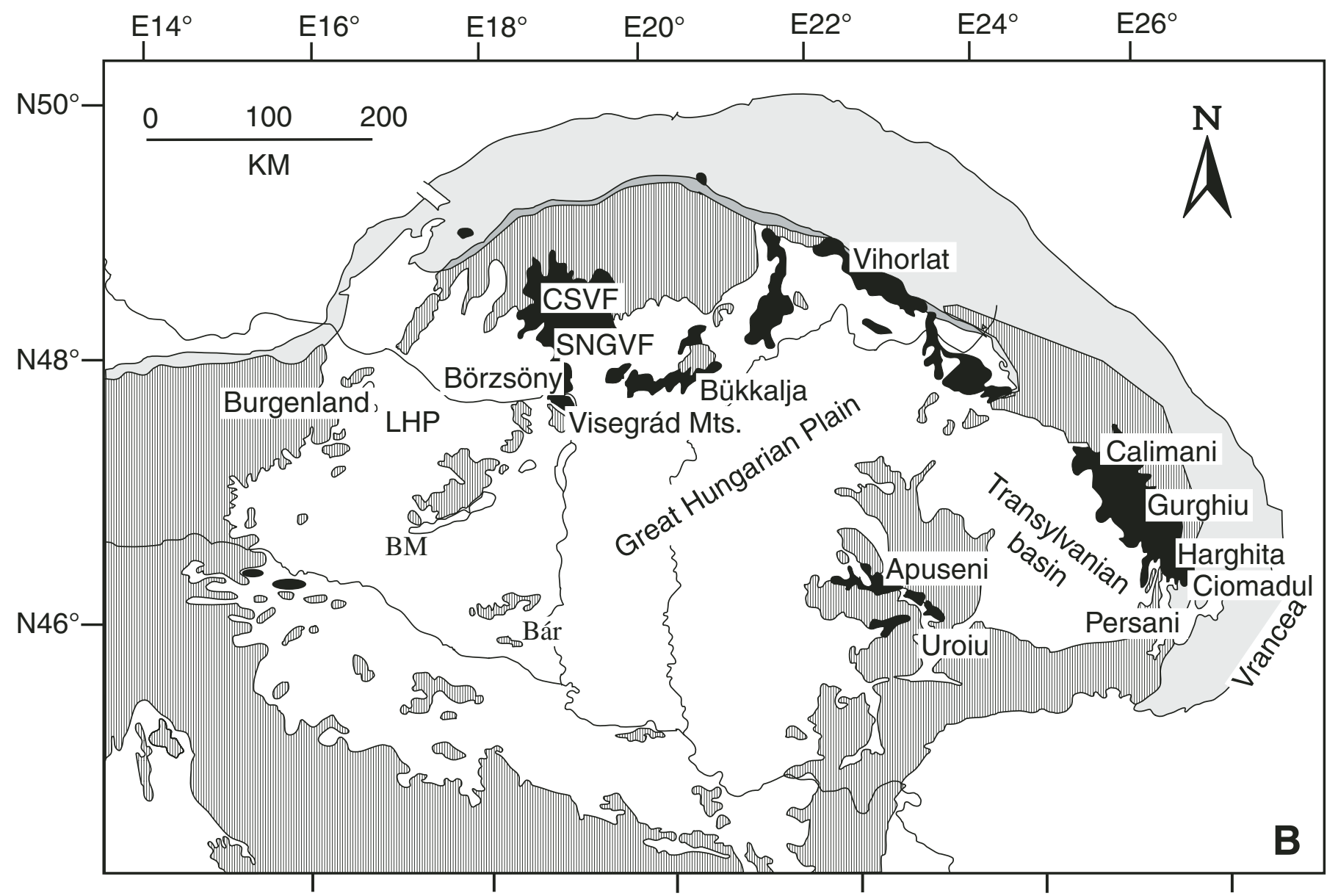

Figure 2 (continued). (B) Index map with the geographic locations mentioned in the text. LHP-Little Hungarian Plain; CSVF-Central Slovakian volcanic field; SNGVF-Stiavnica-Nógrád-Gemer volcanic field; BM-Balatonmária.

Trace-element characteristics of the Carpathian-Pannonian region volcanic rocks are summarized on primitive mantlenormalized (McDonough and Sun, 1995) diagrams (Fig. 5). The majority of them show trace-element patterns with variable enrichment in the large ion lithophile elements (LILE) and $\mathrm{Pb}$, and depletion in $\mathrm{Nb}$, which are typical of subduction-related rocks. The trace-element composition of the rhyolitic pumices shows some variation, mostly in the rare earth elements (REE) and $\mathrm{Zr}$, which was used to distinguish major eruptional units in the area (Harangi et al., 2005). The cognate lithoclasts and the scoriae have trace-element patterns akin to the calc-alkaline andesites. The calc-alkaline andesites and dacites have very similar composition throughout the Carpathian arc, although those found in the western segment of the arc (northern Pannonian Basin) are slightly more enriched in incompatible trace elements at the same $\mathrm{SiO}_{2}$ content than those from the East Carpathians (Fig. 5C). The calc-alkaline andesites of the Apuseni Mountains (Seghedi et al., 2004a) resemble those of the Carpathian arc; however, they have highly variable, and often relatively high, Ba concentrations. The late-stage (9-10 Ma) basalts and basaltic andesites from the northern Pannonian Basin differ significantly from the older calc-alkaline volcanic products. They show much less or even no depletion in $\mathrm{Nb}$ (Fig. 5D), and they resemble the subsequent alkaline basaltic rocks. The potassic and ultrapotassic rocks display an extreme enrichment in incompatible trace elements, but they have depletion in the heavy REEs. The 2 Ma Bár leucitite shows remarkable similarity with the $1.6 \mathrm{Ma}$ potassic trachyandesite of the south Apuseni Mountains (Uroiu; Seghedi et al., 2004a). These rocks have, however, different compositions compared with the Oligocene and Pliocene ultrapotassic rocks from the Dinarides (Fig. 5E; Prelevic et al., 2001, 2005; Cvetkovic et al., 2004) and show significantly higher primitive mantle-normalized $\mathrm{Ba} / \mathrm{Rb}$ and $\mathrm{La} / \mathrm{Yb}$ ratios. The high- $\mathrm{K}$ dacites of the Ciomadul volcano have similar compositional features to the other potassic and ultrapotassic rocks of the CarpathianPannonian region, i.e., strong enrichment in $\mathrm{Ba}$ (primitive mantle-normalized $\mathrm{Ba} / \mathrm{Rb}>1$ ) and depletion in the heavy REEs (Fig. 5F). The trace-element composition of the alkaline mafic rocks resembles the intraplate magmas and that of the Neogene to Quaternary alkaline mafic rocks in Western and Central Europe 


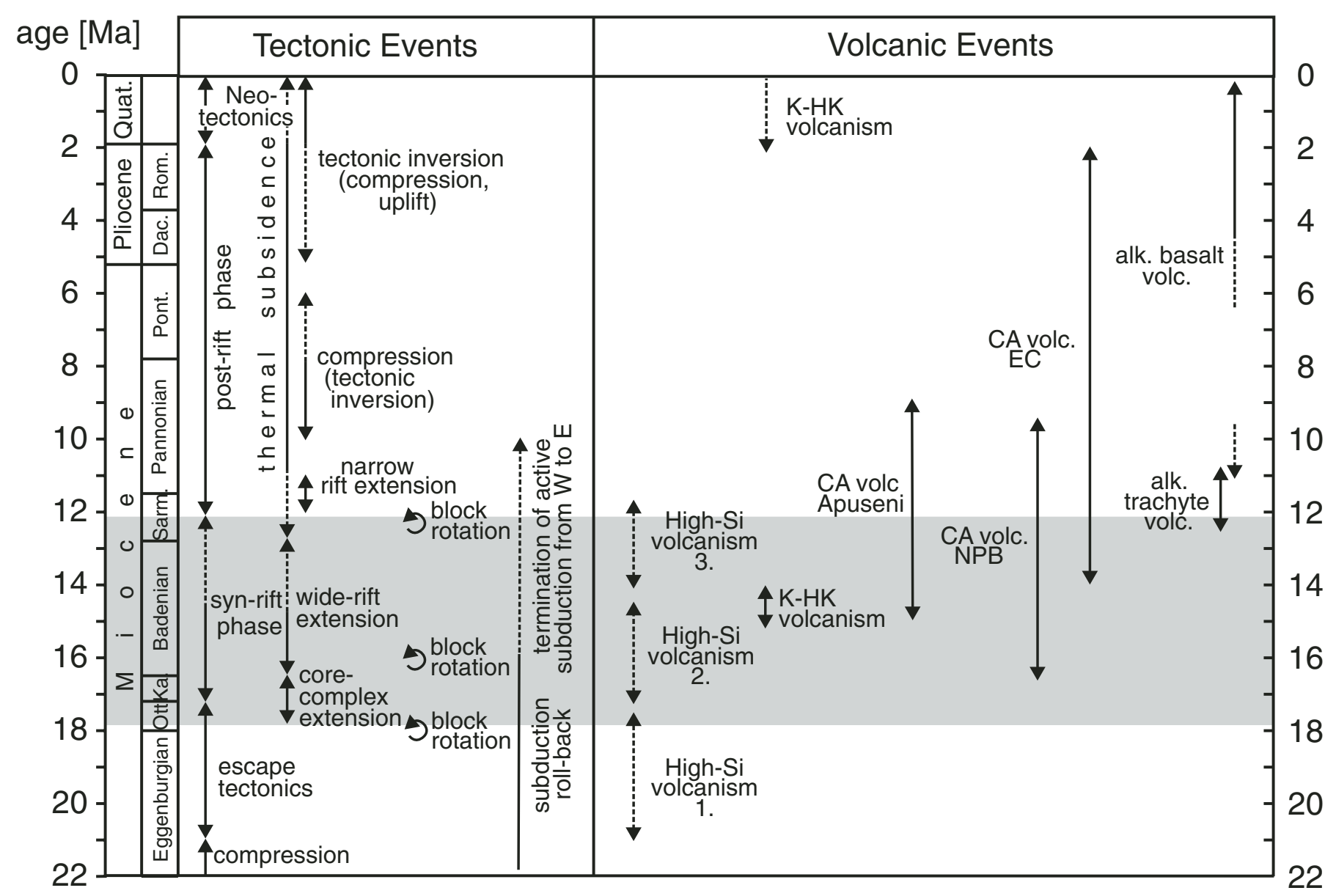

Figure 3. Temporal relationship between the Neogene to Quaternary geodynamic and tectonic events and magmatism in the Carpathian-Pannonian region based on the data of Pécskay et al. (1995a), Fodor et al. (1999), and Tari et al. (1999). CA — calc-alkaline; alk.—alkaline; NPB — northern Pannonian Basin; EC - Eastern Carpathians. HK-high-K.

(Wilson and Downes, 1991). Seghedi et al. (2004b) separated several groups (more than 10) of alkaline basalts based on their age and compositions. However, we distinguish here only two main compositional groups without regard for their age: the first one is characterized by stronger enrichment in incompatible trace elements and a typical negative $\mathrm{K}$ anomaly, whereas the second one has smoother trace-element patterns.

\section{Isotope Compositions}

The Sr and Nd isotopic composition of the CarpathianPannonian region volcanic rocks (Table 2 ) follows a fairly narrow trend from the depleted quadrant of the Sr-Nd diagram toward the enriched segment (Fig. 6), which is similar to that shown by Central Mediterranean volcanic rocks (Peccerillo, 2003). All of the alkaline mafic rocks fall into the depleted isotopic field, such as the majority of Neogene to Quaternary alkaline mafic rocks in Western and Central Europe (Wilson and Downes, 1991; Wilson and Patterson, 2001). The most-depleted end member of this variation trend is a mixture of HIMU (high- $\mu$ mantle) and DMM (depleted mid-ocean-ridge-basalt [MORB] mantle). The largest $\mathrm{Sr}-\mathrm{Nd}$ isotopic variation is shown by the calc-alkaline volcanic rocks. Some of them (e.g., Calimani, East Carpathians, and central Slovakia, Western Carpathians) fall into the depleted quadrant of the diagram, but most of the samples follow a continuous trend in the enriched isotopic field. The potassic-ultrapotassic rocks and the silicic volcanic suite overlap this isotopic trend. The Bár leucitite and the Apuseni potassic trachyandesite have lower initial ${ }^{87} \mathrm{Sr} /{ }^{86} \mathrm{Sr}$ and higher ${ }^{143} \mathrm{Nd} /{ }^{144} \mathrm{Nd}$ isotope ratios than the Neogene ultrapotassic rocks of the Dinarides (Cvetkovic et al., 2004). The Sr-Nd isotopic composition of the shoshonites and high-K dacites in the southeast Carpathians deviates from the calc-alkaline volcanic suites.

In the $\mathrm{Pb}-\mathrm{Pb}$ isotopic diagrams (Fig. 6), the alkaline mafic rocks show a much larger variation than the calc-alkaline rocks. Many of the samples have relatively high ${ }^{207} \mathrm{~Pb} /{ }^{204} \mathrm{~Pb}$ ratios, causing a vertical shift from the Northern Hemisphere reference line (NHRL). The highest ${ }^{206} \mathrm{~Pb} /{ }^{204} \mathrm{~Pb}$ ratio is shown by the oldest alkaline basalts from the Pannonian Basin-Alpine transition zone (Burgenland; Fig. 2B). The calc-alkaline volcanic rocks 


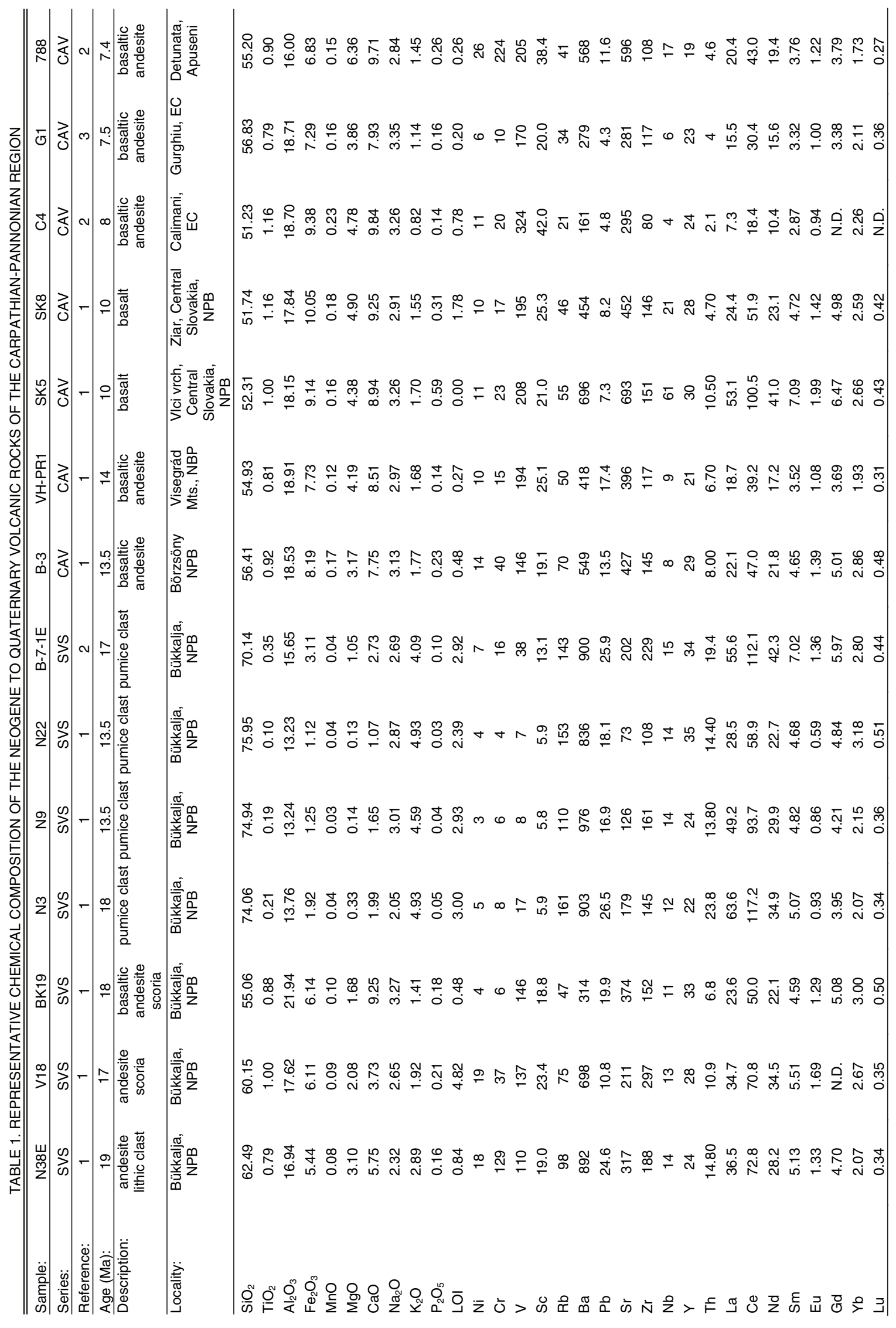




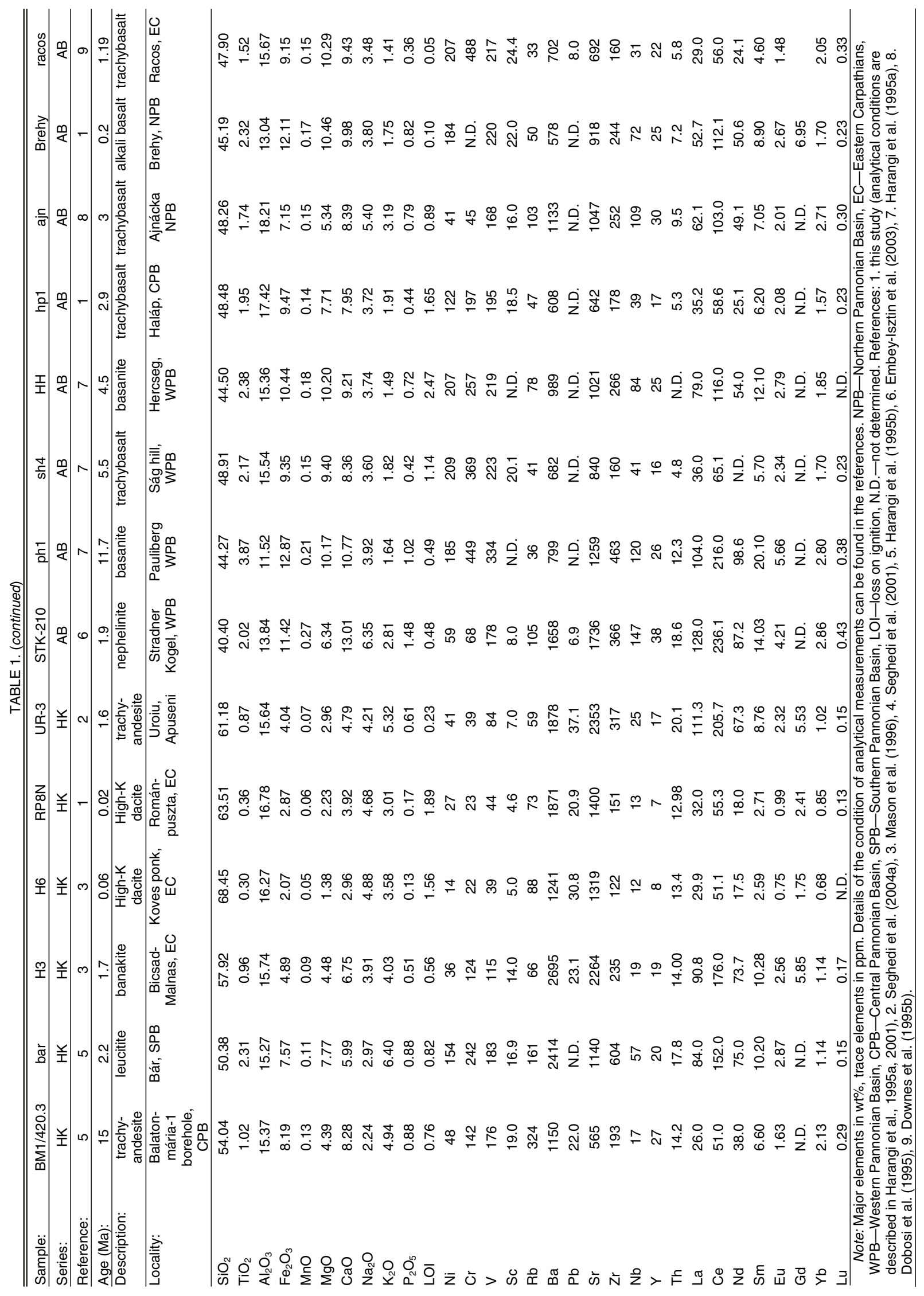


TABLE 2. REPRESENTATIVE ISOTOPE COMPOSITION OF THE NEOGENE TO QUATERNARY VOLCANIC ROCKS OF THE CARPATHIAN-PANNONIAN REGION

\begin{tabular}{lcccccccc}
\hline \hline Sample & Series & Reference & ${ }^{87} \mathrm{Sr} /{ }^{\beta 6} \mathrm{Sr}$ & $\left({ }^{87} \mathrm{Sr} /{ }^{\beta 6} \mathrm{Sr}\right)$ & ${ }^{143} \mathrm{Nd} /{ }^{144} \mathrm{Nd}$ & ${ }^{206} \mathrm{~Pb} /{ }^{204} \mathrm{~Pb}$ & ${ }^{207} \mathrm{~Pb} /{ }^{204} \mathrm{~Pb}$ & ${ }^{208} \mathrm{~Pb} /{ }^{204} \mathrm{~Pb}$ \\
\hline N38E & SVS & 1 & 0.70920 & 0.70897 & 0.51227 & N.D. & N.D. & N.D. \\
BK19 & SVS & 1 & 0.70736 & 0.70727 & 0.51242 & N.D. & N.D. & N.D. \\
N3 & SVS & 1 & 0.71046 & 0.70979 & 0.51225 & 18.837 & 15.686 & 39.044 \\
N9 & SVS & 1 & 0.70799 & 0.70734 & 0.51245 & 18.903 & 15.660 & 38.903 \\
N22 & SVS & 1 & 0.70943 & 0.70787 & 0.51244 & N.D. & N.D. & N.D. \\
B-7-1E & SVS & 2 & 0.71137 & 0.71085 & 0.51222 & N.D. & N.D. & N.D. \\
B-3 & CAV & 1 & 0.70743 & 0.70734 & 0.51253 & 18.944 & 15.678 & 39.031 \\
VH-PR1 & CAV & 1 & 0.70709 & 0.70702 & 0.51242 & 18.914 & 15.682 & 39.030 \\
SK5 & CAV & 1 & 0.70478 & 0.70475 & 0.51268 & 19.186 & 15.676 & 39.178 \\
SK8 & CAV & 1 & 0.70587 & 0.70583 & 0.51254 & 18.884 & 15.657 & 38.875 \\
C4 & CAV & 2 & 0.70552 & 0.70550 & 0.51278 & 18.821 & 15.644 & 38.823 \\
G1 & CAV & 3 & 0.70627 & 0.70625 & 0.51265 & 18.903 & 15.673 & 39.070 \\
788 & CAV & 2 & 0.70440 & 0.70438 & 0.51269 & N.D. & N.D. & N.D. \\
BM1/420.3 & HK & 5 & 0.70978 & 0.70943 & 0.51229 & N.D. & N.D. & N.D. \\
bar & HK & 5 & 0.70503 & 0.70502 & 0.51259 & N.D. & N.D. & N.D. \\
H3 & HK & 3 & 0.70464 & 0.70463 & 0.51263 & 18.574 & 15.66 & 38.785 \\
H6 & HK & 3 & 0.70485 & 0.70484 & 0.51248 & 18.427 & 15.649 & 38.701 \\
UR-3 & HK & 2 & 0.70444 & 0.70443 & 0.51268 & N.D. & N.D. & N.D. \\
STK-210 & AB & 6 & 0.70349 & 0.70349 & 0.51287 & 19.191 & 15.611 & 39.018 \\
ph1 & AB & 7 & 0.70370 & 0.70369 & 0.51279 & N.D. & N.D. & N.D. \\
sh4 & AB & 7 & 0.70428 & 0.70427 & 0.51265 & N.D. & N.D. & N.D. \\
hp1 & AB & 1 & 0.70424 & 0.70423 & 0.51270 & N.D. & N.D. & N.D. \\
ajn & AB & 8 & 0.70324 & 0.70322 & 0.51290 & N.D. & N.D. & N.D. \\
Brehy & AB & 8 & 0.70359 & 0.70359 & 0.51284 & 19.276 & 15.603 & 39.112 \\
racos & AB & 9 & 0.70441 & 0.70441 & 0.51275 & 18.607 & 15.64 & 38.816 \\
\hline
\end{tabular}

Note: Details of the condition of analytical measurements can be found in the references listed in Table 1. N.D.- - not determined.

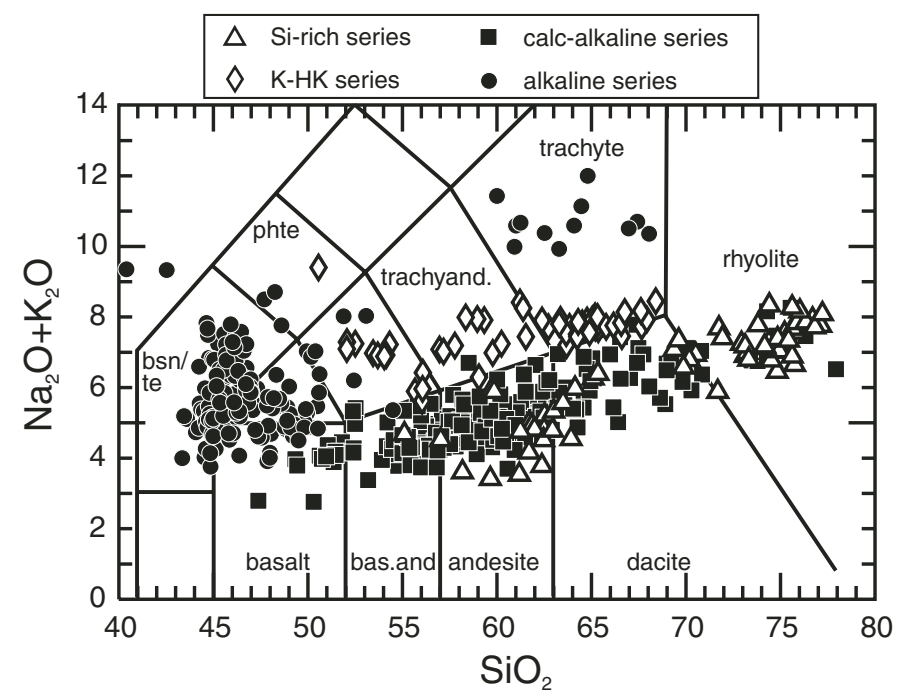

Figure 4. Classification of the Neogene to Quaternary volcanic rocks of the Carpathian-Pannonian region in the $\mathrm{SiO}_{2}$ versus $\mathrm{Na}_{2} \mathrm{O}+\mathrm{K}_{2} \mathrm{O}$ (total alkali silica [TAS]) diagram (Le Bas et al., 1986). References for the data are found in Table 1; bsn-basanite; te- tephrite; phtephonotephrite; trachyand - trachyandesite. HK — high-K. have much more restricted $\mathrm{Pb}-\mathrm{Pb}$ isotope ratios. The shoshonites of the southeast Carpathians differ from the calc-alkaline suites and have lower ${ }^{206} \mathrm{~Pb} /{ }^{204} \mathrm{~Pb}$ ratios, while the Miocene rhyolitic pumices fall into the calc-alkaline field.

\section{DISCUSSION}

The Carpathian-Pannonian region has had a complex tectonic evolution over the last 20 m.y., involving lateral escape of a large tectonic block from the Alpine region, subduction, and lithospheric extension (Csontos et al., 1992; Kovač et al., 1998; Fodor et al., 1999). This geodynamic scenario was accompanied by eruption of a wide range of magmas. During the last decade, a large amount of geochemical data has been published; however, the relationship between the tectonic events and the magmatism is still controversial (e.g., Szabó et al., 1992; Lexa and Konečný, 1998; Nemčok et al., 1998; Seghedi et al., 1998, 2004a, 2004b, 2005; Harangi, 2001a; Konečný et al., 2002). A fundamental remaining question is what exact processes were responsible for melt generation at depth, particularly in the upper mantle.

One major cause of melting could be decompression of fertile mantle during upwelling. Lithospheric extension triggers melting in fairly shallow parts of the mantle, whereas upwelling of relatively hot mantle material could lead to partial melting at 


\section{Si-rich volcanic suite}
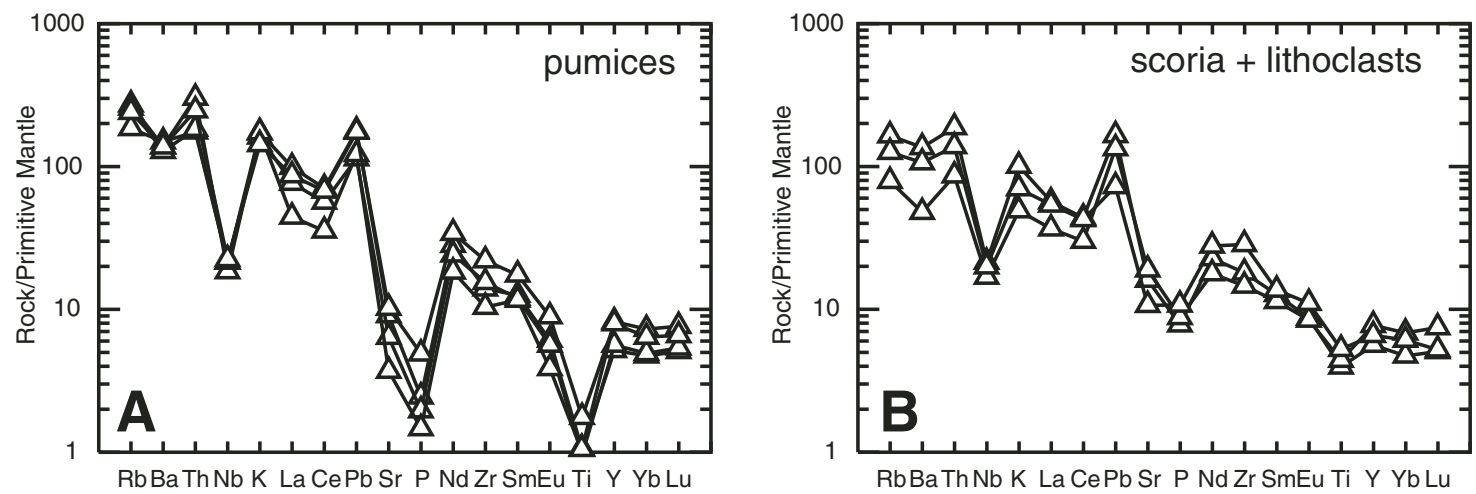

Calc-alkaline volcanic suite
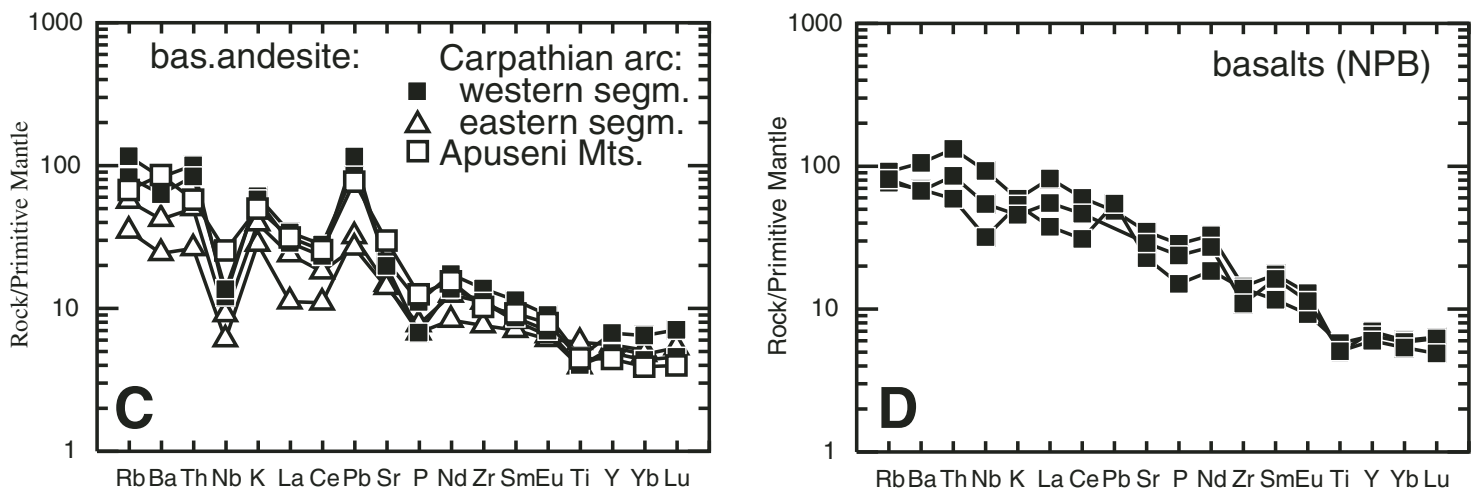

\section{Potassic-Ultrapotassic rocks}
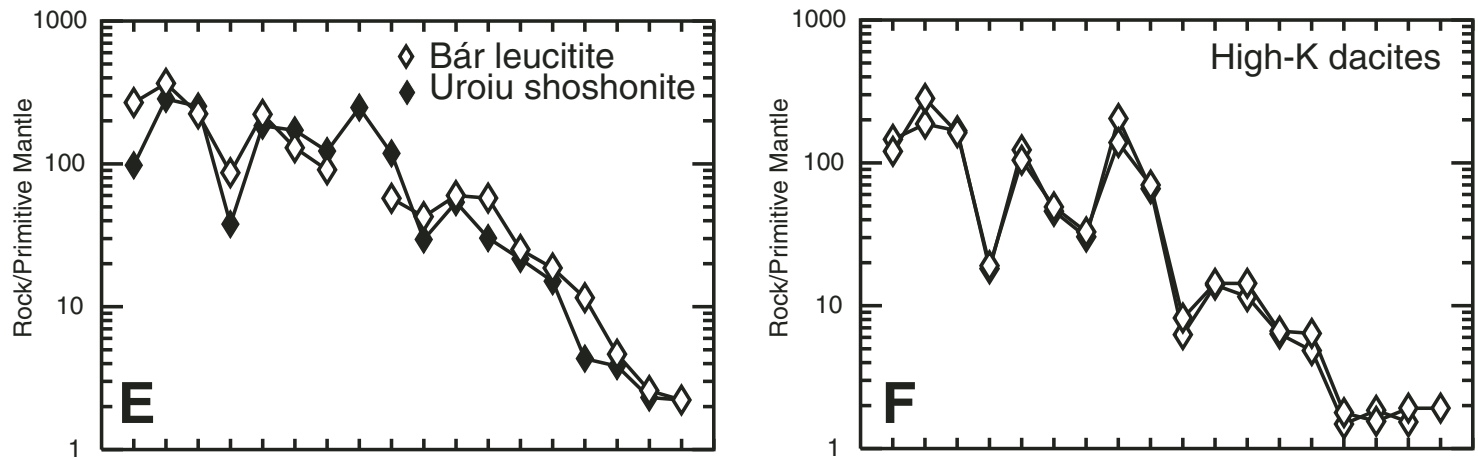

RbBaTh Nb K La CePbSr P NdZrSmEu Ti Y Yb Lu

RbBaThNb K LaCePb Sr P NdZrSmEu Ti Y Yb Lu

\section{Alkaline basalts}
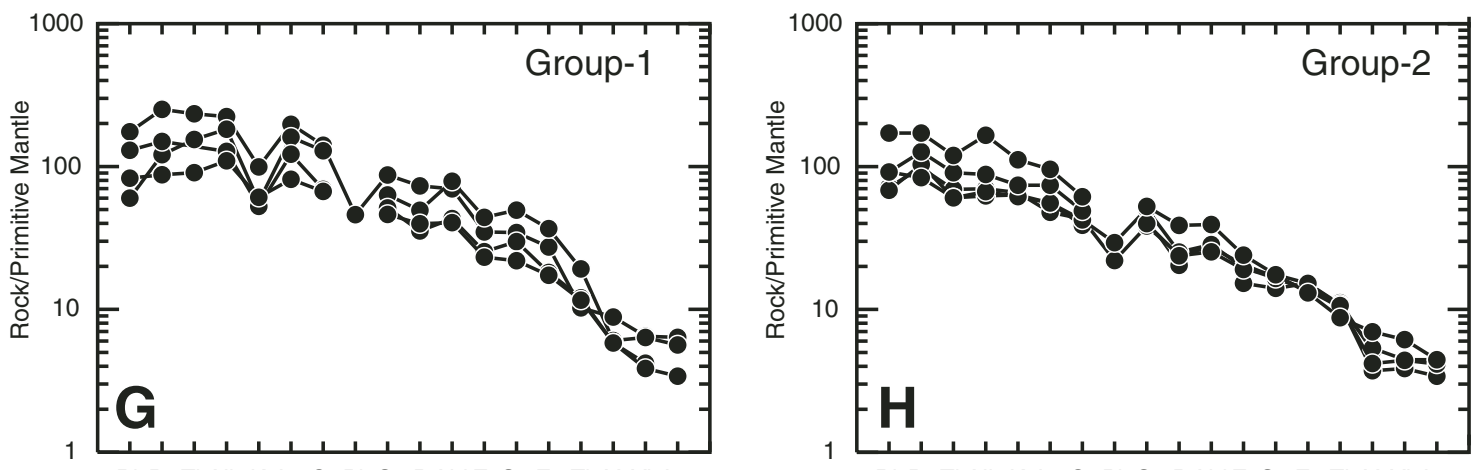

RbBaThNb K La CePb Sr P NdZrSmEu Ti Y Yb Lu

RbBaThNb K La CePb Sr P NdZrSmEu Ti Y Yb Lu 
greater depth. However, another important factor is the presence of volatiles, which decrease the melting temperature. Volatiles control melt generation beneath subduction zones, where dehydration of the subducted slab results in thorough metasomatism of the mantle wedge (Gill, 1981; Pearce and Peate, 1995). Volatilebearing peridotites also occur in the lower lithosphere, far from subduction zones, as revealed by amphibole- and phlogopitebearing mantle xenoliths enclosed by alkali basalts. Thus, in a melt generation model related to the thinning of the continental lithosphere, the first magmas are most readily generated by melting of the metasomatized parts of the lithospheric mantle, followed by melting of the more-depleted upwelling asthenosphere (Gallagher and Hawkesworth, 1992; Wilson, 1993). In the Carpathian-Pannonian region, both decompression melting and volatile-induced melting probably have played a role in magma generation over the last 20 m.y. Volcanic activity in this region continued until quite recently $(<500 \mathrm{ka})$, suggesting that the conditions in the upper mantle could still enable magma production in the future. Thus, it is important to identify where melt generation processes have taken place, what triggered melting, and whether further melting process leading to the renewal of the volcanic activity could be predicted. In the following section, we investigate how the main tectonic processes, such as subduction and extension, and active mantle plume upwelling, could influence the magmatism in the Carpathian-Pannonian region.

\section{Role of Subduction}

Cretaceous to Neogene flysch sediments around the presentday Carpathians suggest that subduction in this area should start in the Late Cretaceous and continued during the Neogene (Horváth and Royden, 1981; Sandulescu, 1988; Csontos et al., 1992). Approximately $260 \mathrm{~km}$ shortening is estimated to have occurred in the Outer Carpathians from the middle Oligocene to the middle Miocene (Roure et al., 1993; Behrmann et al., 2000), which was coeval with the extension of the Pannonian Basin (Royden et al., 1983; Csontos et al., 1992). A major feature of the CarpathianPannonian region is an arcuate belt of calc-alkaline volcanic complexes composed mostly of andesites and dacites along the inner side of the thrusted Carpathians (Fig. 2A). The andesites and dacites show geochemical characteristics (increase of LILEs and $\mathrm{Pb}$, depletion in $\mathrm{Nb}$ and $\mathrm{Ti}$; Fig. 5C) typical of subductionrelated magmas. Thus, the formation of the Carpathian volcanic arc has been commonly interpreted as a consequence of subduction process (Bleahu et al., 1973; Balla, 1981; Szabó et al., 1992; Downes et al., 1995a).

In present-day subduction zones, volcanic arcs develop roughly at $\sim 110 \mathrm{~km}$ and $\sim 170 \mathrm{~km}$ above the subducting slab,

Figure 5. Primitive mantle-normalized (McDonough and Sun, 1995) trace-element patterns of representative samples of the Neogene to Quaternary volcanic rocks of the Carpathian-Pannonian region. For references for the data, see Table 1. NPB - northern Pannonian Basin. and the width of the volcanic arc is a function of the subduction angle (Tatsumi and Eggins, 1995; Tatsumi, 2005). The subducting oceanic slab undergoes continuous metamorphism and dehydration. The aqueous fluid phases released by dehydration reactions enter the lower part of the mantle wedge that is dragged down by the subducting plate and form hydrous phases such as amphibole and phlogopite (Pearce and Peate, 1995). Breakdown of these minerals at around 110 and $170 \mathrm{~km}$ depths results in fluid flux into the overlying mantle wedge, which decreases the solidus and initiates partial melting. Due to the advancement of the precise measurements of the short-lived U-series isotopes, it has been discovered that dehydration of the subducting slab, formation of magma in the
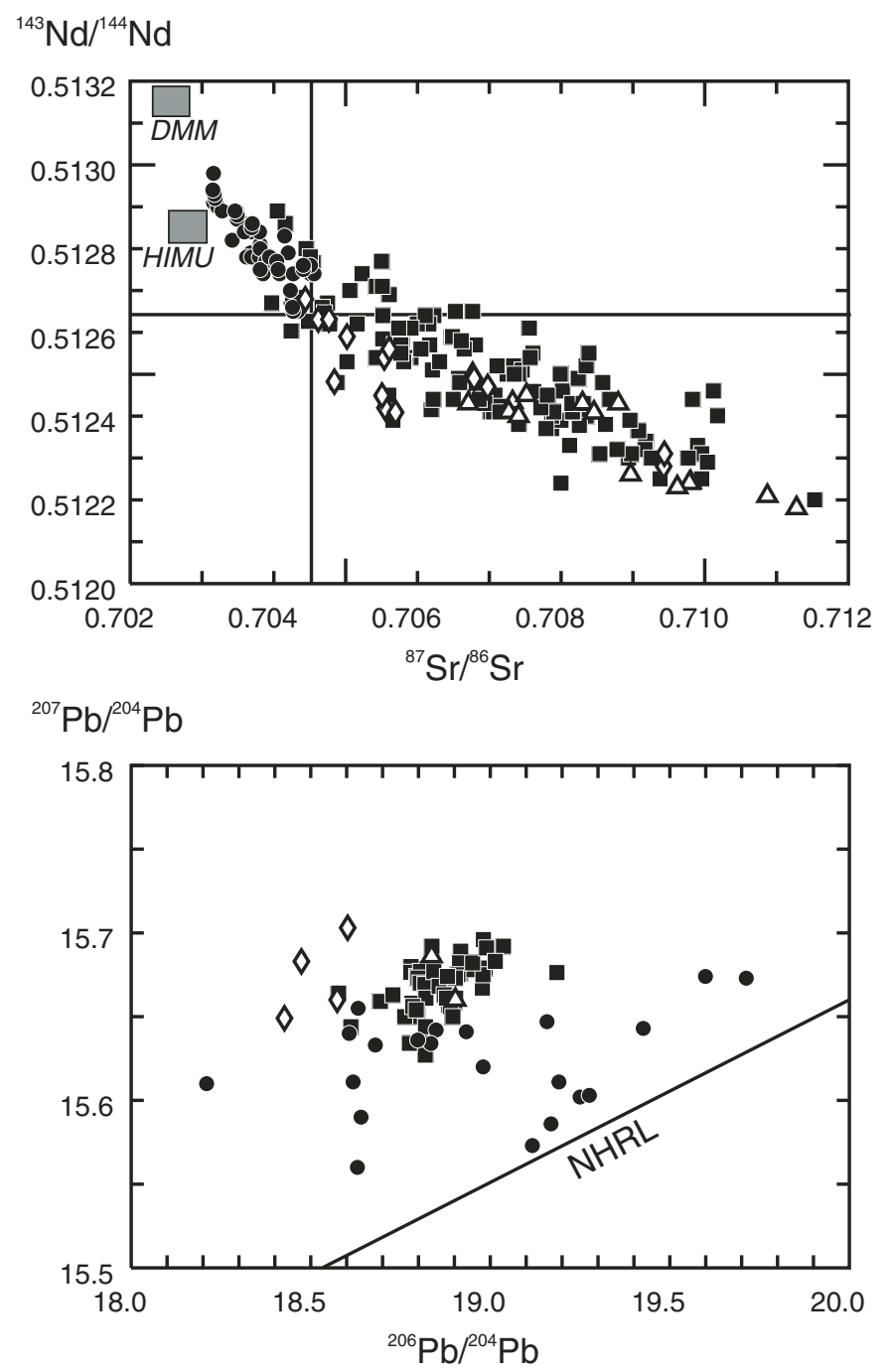

Figure 6. ${ }^{143} \mathrm{Nd} /{ }^{144} \mathrm{Nd}$ versus ${ }^{87} \mathrm{Sr} /{ }^{86} \mathrm{Sr}$ and ${ }^{207} \mathrm{~Pb} /{ }^{204} \mathrm{~Pb}$ versus ${ }^{206} \mathrm{~Pb} /{ }^{204} \mathrm{~Pb}$ isotope diagrams for the Neogene to Quaternary volcanic rocks of the Carpathian-Pannonian region. DMM (depleted mid-ocean-ridge basalt [MORB] mantle) and HIMU (high- $\mu$ mantle) are mantle components as defined by Zindler and Hart (1986). The symbols are explained in Figure 4. The references of the data can be found in Table 1. NHRLNorthern Hemisphere reference line. 
mantle wedge, and volcanic eruption could take place in a relatively short period, i.e., within a few tens of thousands of years (Elliott et al., 1997). This may indicate that addition of aqueous fluids into the mantle wedge could trigger major melt generation ("flux melting"; Gill, 1981; Hawkesworth et al., 1993; Stolper and Newman, 1994; Iwamori, 1998). In addition, dehydration and melting of subducted sediments may also contribute to the formation of the arc magmas. The U-Th disequilibrium isotope data suggest that the time scale (from a few tens of thousands of year to $>100$ k.y.) of these processes depends on the subduction rate and/or on the composition of the subducted sediment (Sigmarsson et al., 1990; Gill et al., 1993; Elliott et al., 1997). In this context, one would expect that the Neogene calc-alkaline volcanism along the Carpathians took place contemporaneously with active subduction. The spatial distribution of the volcanic formations and the width of the volcanic complexes (Fig. 2A) suggest a relatively shallow subduction $\left(30-40^{\circ}\right)$ associated with the volcanism on the western segment of the Carpathian arc, whereas a relatively deep subduction $\left(50-60^{\circ}\right)$ to the east. However, there are notable problems with the classic subduction-related magmatism model when applied to this region: (1) the active subduction period as recorded in the flysch sediments (Paleogene to early Miocene) was not associated with arc volcanism; (2) the calcalkaline volcanic activity started when subduction of the oceanic plate ceased, as indicated by the final shortening in the Outer Carpathians (Jiříček, 1979). Thus, this volcanism can be regarded as postcollisional (Seghedi et al., 1998). (3) Calc-alkaline volcanic rocks can be found also in the inner part of the Pannonian Basin, although they are mostly covered by a late Miocene to Quaternary sedimentary sequence (Pécskay et al., 1995a). (4) There is a gradual migration of the volcanism from NW to SE along the East Carpathians, accompanying a general decrease of the volume of the erupted magmas (Pécskay et al., 1995b; Szakács and Seghedi, 1995). (5) The calc-alkaline volcanic complexes in the northern part of the Pannonian Basin (Fig. 2A) are underlain by relatively thin crust and lithosphere $(<30 \mathrm{~km}$ and $<80 \mathrm{~km}$, respectively; Tari et al., 1999), and, most notably, the first eruption occurred just coeval with the synrift phase of the Pannonian Basin. Lexa and Konečný $(1974,1998)$ classified these volcanic rocks as "areal-type," distinguishing them from the "arc-type" volcanic rocks in the East Carpathians.

The apparent time delay between the main period of shortening (i.e., active subduction of an oceanic plate) and the initiation of the volcanism in the East Carpathians was explained by Mason et al. (1998) as a consequence of subduction of a narrow (150 200-km-wide) oceanic basin. In this case, the observed time gap could be consistent with the arrival of the oceanic lithosphere at a depth of $\sim 100 \mathrm{~km}$, where release of aqueous fluids could result in melting in the mantle wedge. However, this would mean that subduction would have started only $\sim 6$ m.y. before the onset of the volcanism, which would appear to be too short a time, considering that active subduction took place throughout the Miocene and possibly from the Cretaceous (Sandulescu, 1988; Sperner et al., 2002). Thus, the fundamental question is: what triggered the arc-type magma generation at depth during and after the continental collision?

The volcanic arc can be subdivided into two parts: in the west (northern part of the Pannonian Basin), the stratovolcanic complexes are situated roughly perpendicular to the Carpathian orogenic belt, extending as far as $200-300 \mathrm{~km}$ from the assumed suture zone in the Outer Carpathians. The volcanism in the west commenced at $16.5 \mathrm{Ma}$, had a paroxysm between 15 and $13 \mathrm{Ma}$, and terminated at $9 \mathrm{Ma}$ (Pécskay et al., 1995a). In contrast, the volcanoes in the east (from the Vihorlat to the Ciomadul, Fig. 2B; eastern part of the Carpathian-Pannonian region) are parallel with the Carpathians, extending only $50-100 \mathrm{~km}$ from the assumed suture zone; at the southeasternmost segment, they developed even on the accretionary wedge (Fig. 2A). The volcanic activity lasted from ca. $14 \mathrm{Ma}$ until $0.02 \mathrm{Ma}$, with a gradual southward migration of the eruptions, and the individual volcanic complexes show relatively short-lived (3-4 Ma) volcanism (Pécskay et al., 1995a, 1995b). The differences in the time and space distribution of the volcanism, in the deep structure beneath the volcanic complexes (thin and thick lithosphere, respectively), and also in the geochemical features may indicate different geodynamic conditions in the western (northern part of the Pannonian Basin) and eastern (eastern Carpathian-Pannonian region) segments of the arc.

\section{Calc-Alkaline Volcanism in the Northern Pannonian Basin}

In the northern Pannonian Basin, the calc-alkaline volcanic complexes occur above a relatively thin lithosphere, and the onset of the volcanism was strikingly coeval with the main rifting period of the Pannonian Basin (Fig. 3). Furthermore, Nemčok and Lexa (1990) described synvolcanic extensional structures in the Central Slovakian volcanic field, Western Carpathians. These features clearly suggest a strong relationship between lithospheric extension and the calc-alkaline magmatism. One of the peculiar characteristics of these volcanic rocks is the relative abundance of almandine garnets in andesites and rhyodacites formed among the first volcanic products (Brousse et al., 1972; Embey-Isztin et al., 1985; Harangi et al., 2001). This mineral is fairly rare in calcalkaline volcanic rocks worldwide (Harangi et al., 2001). Most of the almandines in the Carpathian-Pannonian region are primary, i.e., they were formed from silicate liquid. This occurrence points to a specific condition of the magma genesis, when almandine garnet could form and remain in the magma. Primary Ca-rich $(\mathrm{CaO}>$ $4 \mathrm{wt} \%)$ and $\mathrm{Mn}$-poor $(\mathrm{MnO}<4 \mathrm{wt} \%)$ almandines crystallize from hydrous andesitic magmas at relatively high pressure $(>7 \mathrm{kbar})$ and at temperatures of $900-950{ }^{\circ} \mathrm{C}$ (Green, 1977, 1992). This mineral is not stable at shallow depth; hence, a relatively rapid ascent of the host magma is necessary to preserve the garnets in the volcanic rocks (Fitton, 1972; Gilbert and Rogers, 1989). Thus, the relatively frequent occurrence of garnet-bearing calc-alkaline volcanic rocks in the northern Pannonian Basin could be a sign of change in the regional stress field from compressional to tensional stress, and the calc-alkaline magmatism in this region could be directly related to the extensional phase of the Pannonian Basin (Harangi et al., 2001). This means that ascent of the magmas and their formation 
were controlled mostly by the thinning of the continental lithosphere. The source region of the magmas could have been either in the enriched lithospheric mantle or in the asthenosphere. In the former case, the subduction signature of the volcanic rocks can be explained as having been inherited in the source region, i.e., the magmas could have been generated in the lithospheric mantle metasomatized by subduction-related fluids during the preceding or older subduction events. In the second case, the upwelling asthenosphere would have been modified by slab-derived fluids. One can propose that subduction of the oceanic lithosphere was a still ongoing process at depth even following the continental collision in the upper crustal level. In this case, arc-type melts could have been formed in the mantle wedge due to the volatile flux from the descending slab, and the lithospheric extension only enhanced the ascent of the magmas. This scenario cannot be excluded, but our suggestion is that extension and decompression melting of the passively upwelling upper mantle was the primary control in the formation of magmas, and subduction may have played only an indirect role.

Interpretation of the geochemical composition and the type of source region of the calc-alkaline volcanic rocks is often difficult because crustal processes such as fractional crystallization, magma mixing, and crustal assimilation can obscure the original composition of the magmas. Thus, in the following discussion we use only the data of basalts and basaltic andesites $\left(\mathrm{SiO}_{2}=49-57 \mathrm{wt} \%\right.$; $\mathrm{MgO}$ $>3 \mathrm{wt} \%$ ). These sporadic rocks in the northern Pannonian Basin are slightly more enriched in incompatible trace elements than those from the eastern Carpathian-Pannonian region. Furthermore, they have lower $\mathrm{Zr} / \mathrm{Nb}$ and higher $\mathrm{La} / \mathrm{Y}$ ratios, which could suggest lower degrees of melting or a slightly enriched mantle source. Alternatively, this may indicate lower volatile flux into the mantle wedge from the slab, assuming flux-melting process (Stolper and
Newman, 1994; Reiners et al., 2000). The initial ${ }^{87} \mathrm{Sr} /{ }^{86} \mathrm{Sr}$ isotope ratio of these mafic rocks correlates with the Th/La ratio, but not with the $\mathrm{Ba} / \mathrm{La}$ ratio, implying that crustal contamination (either as source contamination or upper-level assimilation) had a more significant role in the genesis of the magmas than the aqueous fluids released from the subducting slab.

The $\mathrm{Sr}$ and $\mathrm{O}$ isotope data of the calc-alkaline rocks from the northern Pannonian Basin suggest that mantle-derived magmas could mix with lower-crustal metasedimentary silicic melts (Harangi et al., 2001). A similar petrogenetic model was also put forward for the genesis of the Miocene silicic magmas in the northern Pannonian Basin (Harangi, 2001a; Harangi et al., 2005). Seghedi et al. (2004a) proposed that the parent magmas of both of the initial andesitic and rhyolitic volcanic rocks were generated above the downgoing slab at the inception of the backarc extension period in the Carpathian-Pannonian region. Indeed, both volcanic suites have subduction-related geochemical signatures and show many similar compositional features (e.g., similar trace-element patterns of the andesites, overlapping radiogenic isotope ratios; Figs. 5 and 6). However, the early to middle Miocene silicic volcanic rocks are found mostly along the shear zone between the North Pannonian and Tisza microplates, and this areal extent does not seem to be consistent with an origin above a descending slab. Instead, this magmatism could be related directly to thinning of a continental block during the northeastward translation. The $\mathrm{La} / \mathrm{Nb}$, $\mathrm{Th} / \mathrm{Nb}$, and ${ }^{87} \mathrm{Sr} /{ }^{86} \mathrm{Sr}$ isotope ratios decrease (Fig. 7), whereas the ${ }^{143} \mathrm{Nd} /{ }^{144} \mathrm{Nd}$ and ${ }^{206} \mathrm{~Pb} /{ }^{204} \mathrm{~Pb}$ isotope ratios increase in the northern Pannonian Basin calc-alkaline volcanic suite with time. In contrast, the $\mathrm{Ba} / \mathrm{La}$ ratio and the ${ }^{207} \mathrm{~Pb} /{ }^{204} \mathrm{~Pb}$ and ${ }^{208} \mathrm{~Pb} /{ }^{204} \mathrm{~Pb}$ isotope ratios do not show clear temporal change. This compositional variation can be explained by decreasing amounts of lower-crustal component in magma genesis and/or an increasing role of a nonmetasoma-
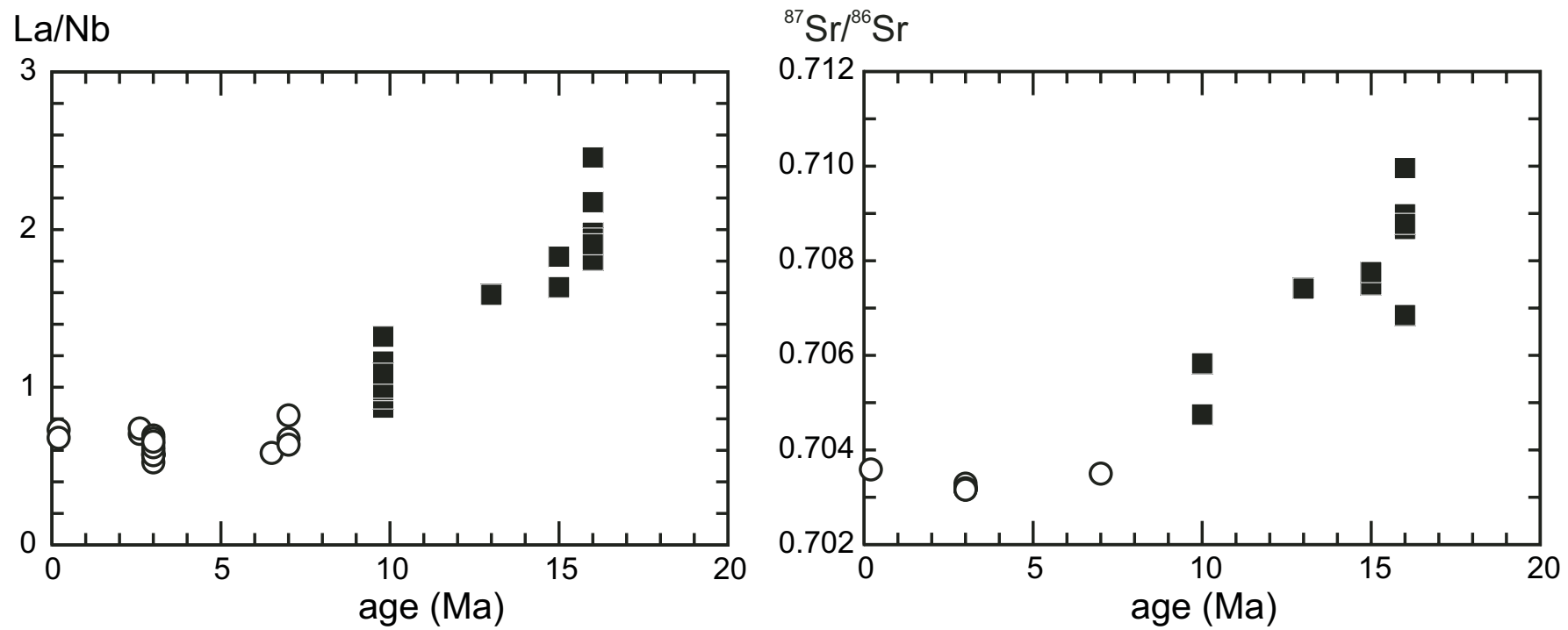

Figure 7. Temporal variation of the $\mathrm{La} / \mathrm{Nb}$ trace-element ratio and initial ${ }^{87} \mathrm{Sr} /{ }^{86} \mathrm{Sr}$ isotope values in the Neogene to Quaternary volcanic rocks of the northern Pannonian Basin. Filled squares indicate the calc-alkaline volcanic rocks (basalts to andesites) from the Central Slovakian volcanic field, whereas the open circles denote the subsequent alkaline mafic rocks from the Stiavnica-Nógrád-Gemer volcanic field (Fig. 2B). 
tized asthenospheric mantle component in the source regions. Both scenarios are consistent with magma generation beneath progressively thinning crust and lithosphere.

In summary, the Miocene silicic and calc-alkaline volcanic rocks in the northern Pannonian Basin do not appear to be directly related to subduction, but to subsequent backarc-type lithospheric extension. The arc-type geochemical character of the magmas can be explained by mixing with variable amounts of lower-crustal melts, although decompression melting of an upwelling mantle material enriched by volatiles from the still-descending slab also cannot be excluded. In this case, the appearance of incompatible trace element-enriched, late-stage transitional basalts and the subsequent alkaline basalts (Dobosi et al., 1995; Konečný et al., 1995) may reflect break-off the subducted slab and ascent of nonmetasomatized, fresh asthenospheric mantle (Konečný et al., 2002; Harangi et al., 2006).

\section{Calc-Alkaline Volcanism in the Eastern Part of the Carpathian-Pannonian Region}

The calc-alkaline volcanic rocks at the eastern CarpathianPannonian region (Szakács and Seghedi, 1995; Mason et al., 1996; Seghedi et al., 2001) are closer to the assumed suture zone, and the volcanoes are situated roughly parallel with the Carpathians (Fig. 2A). The volcanism postdates the major extensional phase of the Pannonian Basin (Fig. 3). The volcanic activity shows a younging toward southeast (Pécskay et al., 1995b). Primary almandine garnets are very rare in these rocks, which belong to low-K tholeiitic series to medium-K calc-alkaline suites (Mason et al., 1996; Seghedi et al., 2001). Thus, it appears that they could be more closely related to the subduction process. However, the volcanic eruptions occurred mostly in the waning phase of subduction, during the postcollisional stage (Seghedi et al., 1998, 2001, 2004a). The areal and temporal distribution of the volcanism has been explained by intense subduction rollback and subsequent slab break-off by Mason et al. (1998) and Seghedi et al. (2001). The notable gradual southeastward shift of the volcanism along the volcanic chain in the eastern Carpathians (from the Calimani to the Ciomadul; Pécskay et al., 1995b) is considered to indicate oblique subduction, tearing, and progressing break-off of the slab and gradual migration of the subducted oceanic plate through the magma-generation zone in the mantle (Mason et al., 1998). The gradual slab break-off appears to be consistent with the short-lived volcanism at the individual volcanic complexes, the strong uplift in the Calimani region, and the less intense uplift at Harghita (Sanders, 1998).

The calc-alkaline volcanic rocks from the eastern CarpathianPannonian region have large variations in $\mathrm{K}_{2} \mathrm{O}$ and incompatible trace elements, but they are generally less enriched in these elements compared with the northern Pannonian Basin calc-alkaline rocks (Fig. 5). Crustal contamination, in addition to high-level fractional crystallization and magma mixing, is thought to have played an important role in the petrogenesis of the magmas in the eastern Carpathians (Mason et al., 1995, 1996). The different origin of the calc-alkaline magmas in the northern Pannonian Basin and the eastern Carpathians is illustrated in the ${ }^{206} \mathrm{~Pb} /{ }^{204} \mathrm{~Pb}$ versus ${ }^{87} \mathrm{Sr} /{ }^{86} \mathrm{Sr}$ isotope diagram (Fig. 8). The volcanic suite of

\section{Western segment}

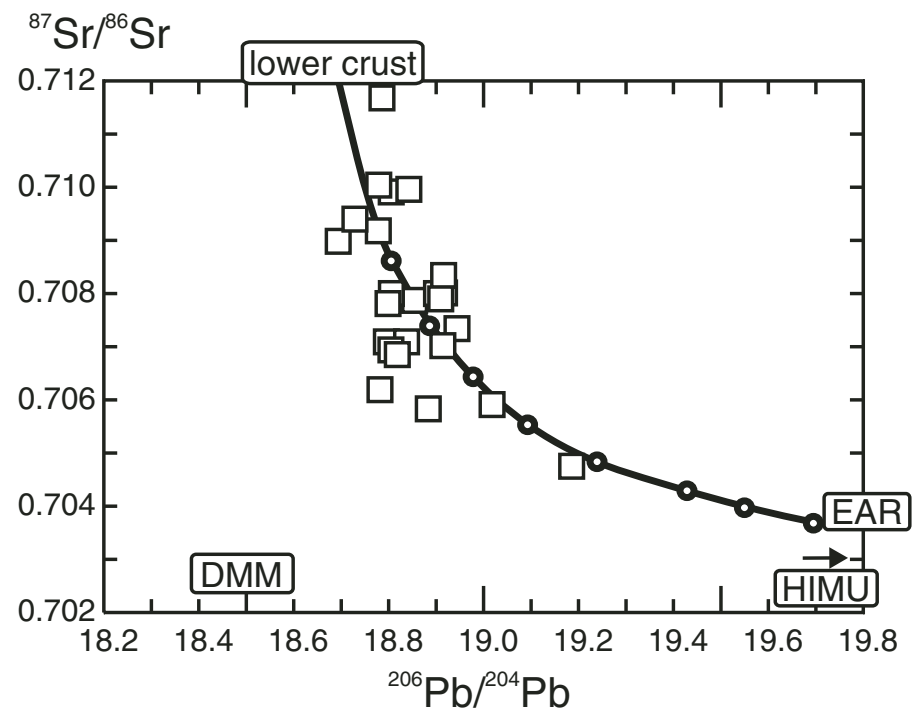

Eastern segment

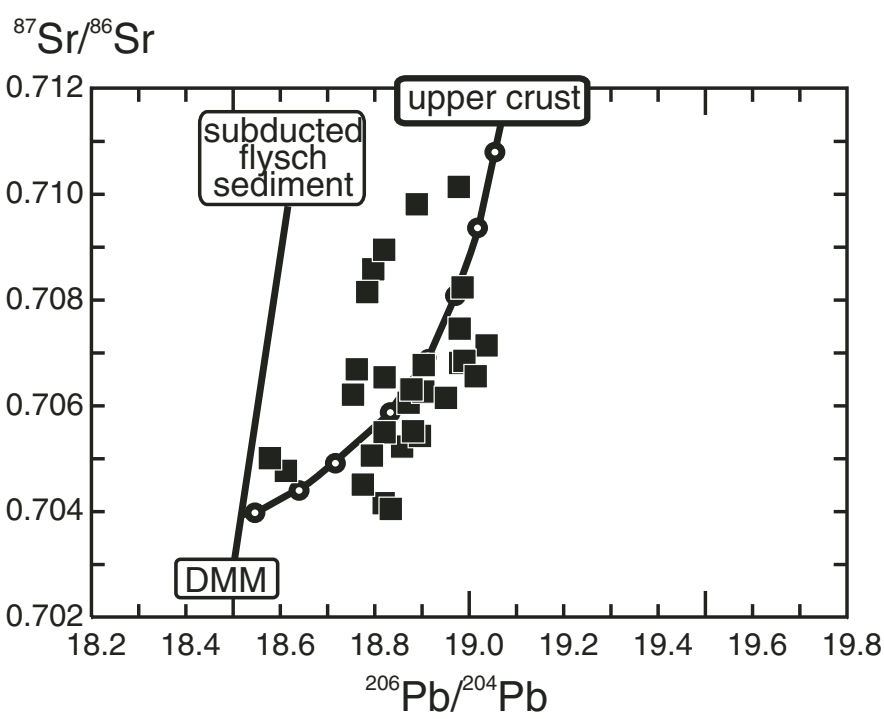

Figure $8 .{ }^{87} \mathrm{Sr} /{ }^{86} \mathrm{Sr}$ versus ${ }^{206} \mathrm{~Pb} /{ }^{204} \mathrm{~Pb}$ diagram for the calc-alkaline volcanic rocks of the western and eastern segments of the Carpathian arc. The volcanic rocks of the two segments define different variation trends. Isotopic variation of the samples from the western segment can be explained by a two-component mixing trend between mafic magmas derived from an enriched mantle and a lower-crustal component, whereas the genesis of the samples from the eastern segment involved a depleted-mantle component contaminated by subducted flysch sediment followed by upper-crustal contamination (Harangi, 2001a). DMM (depleted mid-ocean-ridge basalt [MORB] mantle) and HIMU (high- $\mu$ mantle) are mantle components as defined by Zindler and Hart (1986). EAR - European asthenospheric reservoir. 
the eastern Carpathians shows a contrasting trend compared with the Miocene volcanic rocks from the northern Pannonian Basin, implying different mantle sources and different crustal components. The calc-alkaline magmas of the eastern Carpathians could have formed from a depleted mantle source contaminated by subducted sediments, whereas the calc-alkaline volcanic rocks in northern Pannonian Basin define a mixing trend with an isotopically enriched mantle source and a lowercrustal component (Harangi, 2001a). In summary, the volcanism at the eastern Carpathian-Pannonian region could be related to subduction, but magma generation occurred in a large part during the postcollisional phase, possibly associated with gradual slab break-off.

In addition to the dominant calc-alkaline character of the eastern Carpathian-Pannonian region rocks, the youngest $(<3 \mathrm{Ma})$ volcanic products in the southernmost part of the volcanic chain (South Harghita and Ciomadul; Fig. 2B) are shoshonitic and high-K calc-alkaline and show an abrupt change in chemical composition (Szakács et al., 1993; Mason et al., 1998; Figs. 5 and 9). The most unusual geochemical features of these rocks are the high $\mathrm{Ba}$ and $\mathrm{Sr}$ concentrations and the low $\mathrm{Y}$ content $(\mathrm{Ba}=$ 1000-2000 ppm, Sr = 1000-1600 ppm, Y = 5-15 ppm; Szakács et al., 1993; Mason et al., 1996; Vinkler et al., 2007). Eruption of the potassic magmas was accompanied by development of alkali basaltic volcanoes in the Persany Mountains from 1.2 to 0.6 Ma (Fig. 2B; Downes et al., 1995b; Panaiotu et al., 2004). These alkaline basalts have distinctively higher $\mathrm{La} / \mathrm{Nb}$ and lower $\mathrm{Ce} / \mathrm{Pb}$ ratios than the other alkaline basalts in the Pannonian Basin, suggesting a subduction-related component in their source region (Embey-Isztin and Dobosi, 1995). The basalts contain abundant mantle xenoliths, which do not show subduction-related

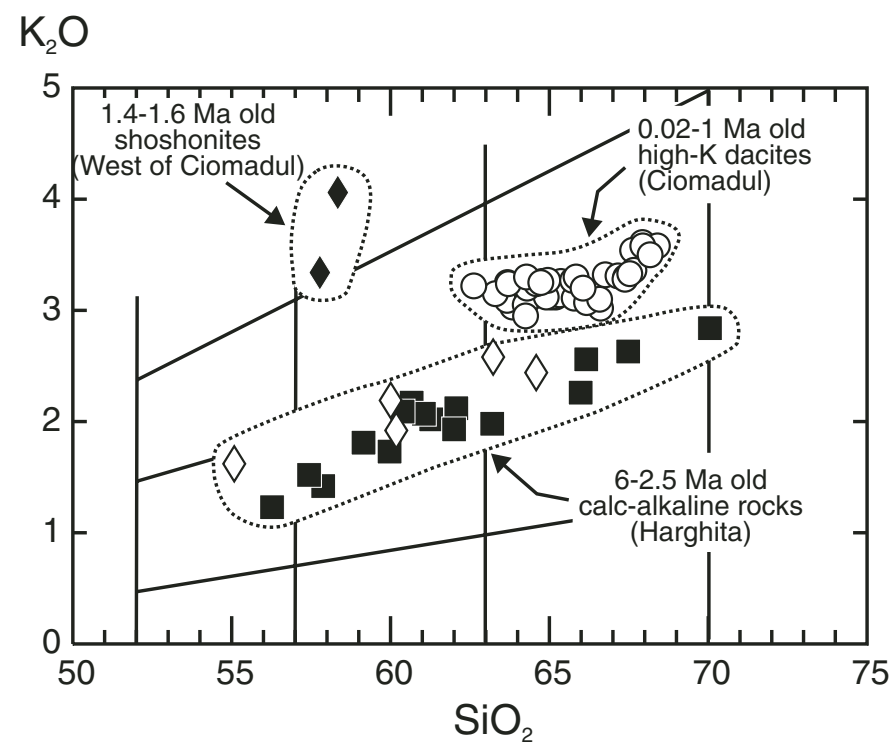

Figure 9. The $\mathrm{SiO}_{2}$ versus $\mathrm{K}_{2} \mathrm{O}$ plot shows abrupt changes in the composition of the calc-alkaline and potassic rocks from the southeastern part of the East Carpathian volcanic chain. metasomatism (Vaselli et al., 1995). Thus, it is inferred that the subduction-related component could reside in the asthenosphere, where alkaline mafic magmas were generated. All of these compositional features imply that subduction played a role in the genesis both of the potassic and the alkaline sodic magmas in the southeastern Carpathians.

The volcanic eruptions at Ciomadul and the Persany region are among the youngest volcanic activities $(<600 \mathrm{ka})$ in the Carpathian-Pannonian region, and the relatively long repose times (several hundreds of thousands of years) between the eruption phases (Pécskay et al., 1995b; Panaiotu et al., 2004) may indicate that renewal of volcanism cannot be unambiguously excluded in the future. This volcanism occurred near the Vrancea zone (Fig. 2B), where intermediate-depth earthquakes represent severe hazards in this part of Europe. The earthquake hypocenters are concentrated in an area with $20 \times 50 \mathrm{~km}$ lateral and $110 \mathrm{~km}$ vertical extent in the 70-180-km-depth range beneath the Vrancea zone (Oncescu and Bonjer, 1997; Sperner et al., 2001). In addition, subcrustal seismic attenuation has been also detected northwest and partly below the Vrancea zone, which can indicate the presence of shallow, hot asthenosphere, possibly with partially melted zones (Hauser et al., 2001; Popa et al., 2005; Russo et al., 2005). It seems to be clear that there is a geodynamic relationship between these processes (volcanic and seismic activity); however, interpretations of the magma genesis and the origin of the vertical slab are fairly controversial.

Most researchers consider that the hanging slab beneath Vrancea is the expression of the latest stage of subduction along the Carpathians, and this can be explained by gradual slab breakoff (Spakman, 1990; Mason et al., 1998; Nemčok et al., 1998; Seghedi et al., 1998; 2004a; Wortel and Spakman, 2000). Mason et al. (1998) suggested that the origin of the youngest volcanic rocks of the eastern Carpathian-Pannonian region is somehow related to the older calc-alkaline magmatism, and they invoked progressive shallowing of slab break-off. Beneath the South Harghita, a slab window could have formed at shallow depth $(<50 \mathrm{~km})$ and been filled by ascending hot asthenospheric mantle. The alkaline basaltic magmas are thought to have been generated by decompression of the uprising asthenosphere. The peculiar geochemical features of the potassic rocks have been interpreted as resulting from increasing slab flux, i.e., increasing dehydration of the slab due to the upwelling hot asthenosphere. The abrupt decrease of the fluid-mobile $\mathrm{B}$ concentration at $3 \mathrm{Ma}$ in the eastern CarpathianPannonian region rocks (Fig. 10), however, does not support this model. Furthermore, Sperner et al. (2001) emphasized that the subducted slab beneath the southeast Carpathians is still fixed vertically, and thus no slab window has been generated yet. The enrichment of LILEs and depletion of Y result in the high $\mathrm{Sr} / \mathrm{Y}$ ratios in potassic rocks that led Seghedi et al. (2004a) to propose an adakitic, i.e., slab melting, origin of the magmas. Nevertheless, the reasons and mechanism of slab melting in this geodynamic setting remain for further investigations.

It is remarkable that the change in the composition of the erupted magmas in the southeastern part of the eastern Carpa- 
B

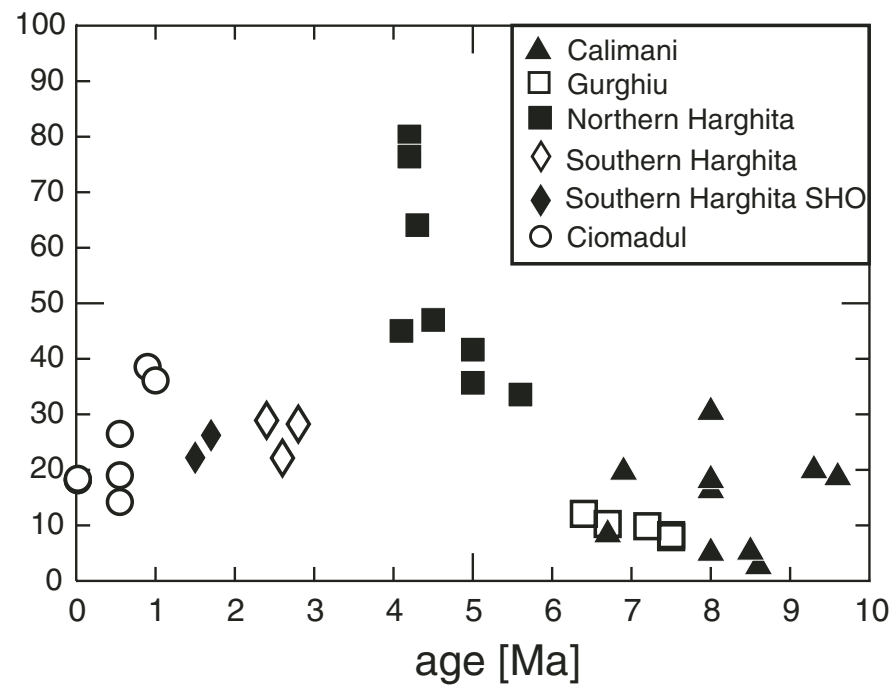

Figure 10. Temporal variation of boron (B) concentration (Gméling et al., 2007) in the Neogene to Quaternary volcanic rocks of the East Carpathians. Note the sudden decrease of boron content at $3 \mathrm{Ma}$. SHO - shoshonites.

thians corresponds to a significant structural feature, i.e., the position of the Trotus line, which separates two main crustal blocks with contrasting thermomechanical characters (Cloetingh et al., 2004). This resulted in different types of collision with stable subduction even during the postcollisional stage to the northwest and an unstable character of the subduction (gravitational sinking stretched body) to the southeast. Therefore, evolution of the southeastern and northwestern segments of the eastern Carpathians could have been somehow independent from one another. It is remarkable that north of the Vrancea zone, no high-velocity seismic anomalies have been shown by seismic tomographic models in the upper mantle above $400 \mathrm{~km}$ (Wortel and Spakman, 2000), i.e., no subducted slab can be detected beneath the Calimani-Harghita volcanic chain.

As an alternative for the slab break-off model, horizontal delamination of the lower part of the continental lithosphere following subduction (Doglioni, 1993; Gîrbacea and Frisch, 1998; Chalot-Prat and Gîrbacea, 2000; Sperner et al., 2001, 2004; Gvirtzman, 2002) or without any subduction (Knapp et al., 2005) has been suggested. Delamination of the lower lithosphere could initiate an asthenospheric mantle flow and provide heat to generate small-volume potassic magma in the metasomatized regions of the lithospheric mantle. In this scenario, the extreme high $\mathrm{Ba}$ and $\mathrm{Sr}$ content of the South Harghita rocks reflects a LILEenriched source, similar to that of the Bár leucitite and the Uroiu shoshonite in the Carpathian-Pannonian region (Fig. 5E). The depletion of the heavy REEs can be interpreted both by the presence of residual garnet during the partial melting (Mason et al., 1998), but also by high-pressure amphibole fractionation. Abundance of high-Al amphiboles in the Ciomadul dacites (South
Harghita; Fig. 2B; Vinkler et al., 2007) supports the latter suggestion. Contemporaneously, the upwelling asthenosphere could have undergone decompression melting resulting in the alkaline mafic magmas that fed the Persani basalt volcanoes.

\section{Apuseni}

In addition to the calc-alkaline volcanic arc along the Carpathians, Miocene calc-alkaline volcanic rocks occur also within the inner part of the Pannonian Basin. They can be found mostly in the Tisza unit, suggesting a relationship with retreating subduction. However, this is an area that underwent major lithospheric extension during the Miocene. The majority of the volcanic formations are covered by late Miocene to Quaternary sediments; therefore, it is difficult to evaluate the exact spatial distribution and the volume of the volcanic formations. Yet, their large areal extent and their age (Pécskay et al., 1995a) may indicate a direct relationship with backarc extension rather than with active subduction.

In the Apuseni Mountains, basaltic andesites and andesites, formed from 14.5 to $7.5 \mathrm{Ma}$, can be found on the surface (Pécskay et al., 1995a; Seghedi et al., 1998, 2004a). They have similar, subduction-related geochemical compositions to the other andesites in the Carpathian arc (Fig. 5C). Thus, Sperner et al. (2004) interpreted the origin of these rocks to be related to a Miocene shallow subduction. The oceanic slab subsequently rolled back and reached the present vertical position beneath the Vrancea zone. However, this interpretation is not consistent with the fact that calc-alkaline volcanism occurred also along the eastern Carpathian-Pannonian region in the same period $\sim 250 \mathrm{~km}$ east of the Apuseni Mountains (Pécskay et al., 1995b). Furthermore, the length of the slab would exceed the assumed width of the oceanic basin (200-300 km; Roure et al., 1993). Without the evidence for active subduction beneath the Apuseni during the middle to late Miocene, the subduction-related character of these rocks can be explained as inherited in their source regions. Remobilization of the metasomatized portion of the lithospheric mantle could be due do contemporaneous block rotation (Patrascu et al., 1994) and thinning of the lithosphere (Seghedi et al., 1998, 2004a).

\section{Role of Extension}

The main extensional phase of the Pannonian Basin, usually defined by the age of the synrift sediments, occurred between $17 \mathrm{Ma}$ and $13 \mathrm{Ma}$, or locally up to $11 \mathrm{Ma}$ (Horváth, 1995). However, it started even earlier in the western part of the CarpathianPannonian region (20-21 Ma; Sachsenhofer et al., 1997; Tari et al., 1999). Before rifting, the Carpathian-Pannonian region was characterized by thick crust and lithosphere inherited from earlier compressional events in the Alpine region. The northeastward lateral escape of the North Pannonian block started in the early Miocene (20-21 Ma; Fodor et al., 1999; Márton and Fodor, 2003) and was accompanied by block rotations, which together resulted in opening of strike-slip basins (Sztanó and Tari, 1993). The beginning of Neogene volcanic activity with eruption of silicic magmas in the Carpathian-Pannonian region just coin- 
cides with these events (Fig. 3). The early Miocene pyroclastic deposits can be found mostly along the contact zone of the North Pannonian and Tisza blocks, implying that there was a close relationship between the magmatism and the lateral movements of the continental blocks (Szabó et al., 1992). Subsequently, deposition of silicic volcaniclastic material shifted northeastward, but remarkably, it overlies the areas with thin crust and lithosphere. Presently, most of these rocks are covered by late Miocene to Quaternary sediments beneath the Great Hungarian Plain (Fig. 2B). However, exploratory boreholes revealed that their thickness could locally exceed $2000 \mathrm{~m}$ (Széky-Fux and Kozák, 1984). Although, the spatial and temporal distribution of the silicic volcanic rocks indicates a strong relationship with the extension of the Pannonian Basin, their composition shows a subduction-related component (Figs. 5A and 5B). The radiogenic isotope ratios of the rhyolitic pumices are similar to those of the early stage calc-alkaline volcanic rocks in the northern Pannonian Basin, whereas the isotopic composition of the andesitic lithic clasts in the ignimbrites resembles the calc-alkaline basaltic andesites and andesites (Fig. 6). Therefore, Seghedi et al. (2004a) considered them to be part of the calc-alkaline volcanism and interpreted their origin in the context of active subduction.

The early stage rhyolites have a strong crustal component (high ${ }^{87} \mathrm{Sr}{ }^{86} \mathrm{Sr}$ isotope ratios; Harangi, 2001a; Seghedi et al., 2004a); however, the isotopic composition of their cognate andesite lithic clasts (Fig. 11) indicates that the primary magmas could have originated in the mantle. Thus, mixing of mantlederived and lower-crustal-derived magmas is inferred in the genesis of the Miocene silicic volcanic rocks of the CarpathianPannonian region. Melting of the lower crust requires either emplacement of large amounts of mafic magma at the base of the crust (Lexa and Konečný, 1998; Konečný et al., 2002) or extreme thinning of the lower lithosphere resulting in ascent of hot asthenosphere. The silicic volcanism lasted for $8 \mathrm{~m}$.y. with repetitive explosive eruptions. The initial ${ }^{87} \mathrm{Sr} r{ }^{86} \mathrm{Sr}$ isotope ratios of the pumices decrease, while the ${ }^{143} \mathrm{Nd} /{ }^{144} \mathrm{Nd}$ isotope ratios increase with time (Fig. 11), implying a decreasing amount of crustal component in their genesis. This is consistent with a gradually thinning continental plate.

The compositional similarity of the 14-16 Ma andesitic lavas in the northern Pannonian Basin and the andesitic lithoclasts in the Miocene silicic ignimbrites suggests that the primary magmas could have been derived from a similar source region. This source region should have been modified by subduction-related fluids. The calc-alkaline and the silicic volcanism occurred partly coeval, although in different areas of the Carpathian-Pannonian region. As we discussed in the previous section, many line of evidence support the hypothesis that melt generation supplied the calc-alkaline volcanism in the north was directly related to the extensional phase of the Pannonian Basin, and we infer that this tectonic event was also the primary cause of the silicic volcanism. A similar scenario, i.e., extension-related calc-alkaline and silicic volcanism, has been described to explain the evolution of the Basin and Range Province, western United States (Gans

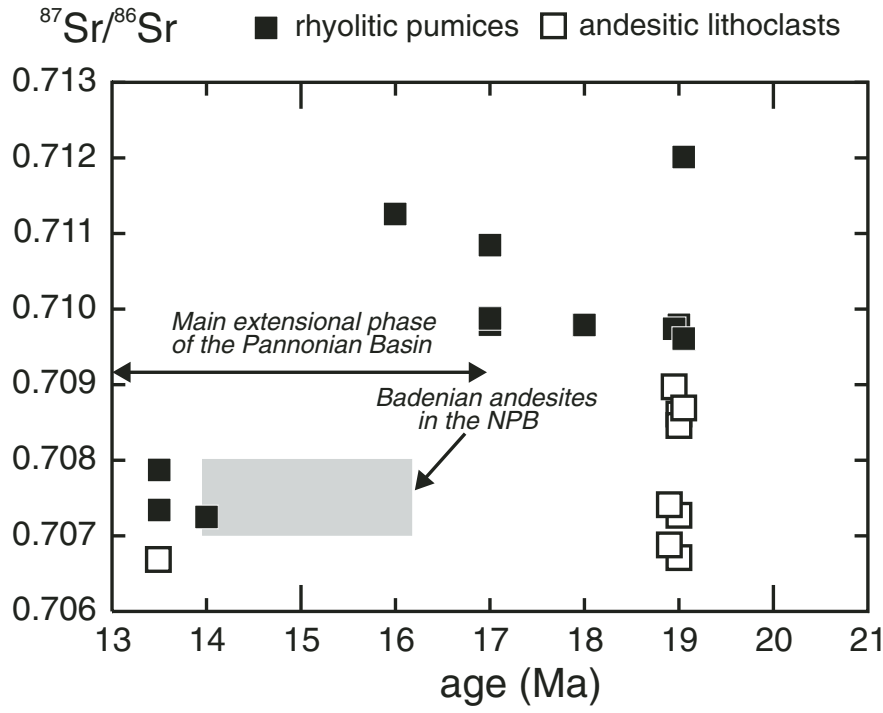

Figure 11. Temporal variation of the initial ${ }^{87} \mathrm{Sr} /{ }^{86} \mathrm{Sr}$ isotope ratios of the pumices (filled squares) and cognate andesitic lithoclasts (open squares) from the Miocene silicic volcanic suite of the CarpathianPannonian region. The ${ }^{87} \mathrm{Sr} /{ }^{86} \mathrm{Sr}$ isotope range of the $14-16 \mathrm{Ma}$ calcalkaline andesites from the northern Pannonian Basin (NPB) is also presented for comparison. The large variation of isotope values in the 19 Ma silicic ignimbrites can be explained by assimilation combined with fractional crystallization processes or various mixing of mantlederived magma with lower-crustal melts. The gradual decrease of ${ }^{87} \mathrm{Sr} /{ }^{86} \mathrm{Sr}$ isotope ratios of the rhyolitic pumices is consistent with the significant thinning of the lithosphere and, thus, the decrease of the crustal component.

et al., 1989; Hawkesworth et al., 1995) and the Western Anatolia (Seyitoglu et al., 1997; Wilson et al., 1997).

In contrast to the intensive early to middle Miocene silicic and calc-alkaline magmatism in the central and eastern part of the Pannonian Basin, there are only sporadic occurrences of Middle Miocene volcanic rocks in the western part of the region. Significantly, these rocks, found in the Styrian Basin and south of Lake Balaton (Balatonmária-1 borehole; Fig. 2B), are potassic and ultrapotassic (Harangi et al., 1995b; Harangi, 2001b). They were formed 14-16 Ma (Pécskay et al., 1995a) and show similar chemical compositions. In spite of the subduction-related features (increase of LILEs and $\mathrm{Nb}$ trough in the normalized traceelement patterns; Harangi, 2001b), there is no evidence for contemporaneous subduction. Small-volume ultrapotassic magmas are thought to be generated in the continental lithospheric mantle in response to thinning of the lithosphere or to the heat flux of upwelling hot mantle beneath the continental plate (McKenzie, 1989; Thompson et al., 1990). In the Carpathian-Pannonian region, the striking coincidence with the main rifting phase of the Pannonian Basin supports the first explanation.

In summary, the Carpathian-Pannonian region provides a natural example where backarc extension of a continental plate is associated with calc-alkaline to silicic volcanism. This can be explained by the extensive subduction-related metasomatism in 
the mantle before the lithospheric stretching. Flat subduction beneath a thick continental lithosphere could have prevented volcanic activity during the Paleogene. However, subduction rollback and the related backarc extension during the middle Miocene would have remobilized the fluid-metasomatized mantle regions. The western part of the Carpathian-Pannonian region was too far from the subduction zone; therefore, its underlying mantle underwent less or no slab fluid-related modification, and, hence, only sporadic eruptions of potassic to ultrapotassic magmas occurred during the synrift phase.

Alkaline basaltic volcanism was widespread in the Carpathian-Pannonian region, but it postdated the peak of extension, similar to what has been observed in the Basin and Range Province of the western United States (Fitton et al., 1991; Hawkesworth et al., 1995). In the Pannonian Basin, the alkaline volcanism started at $11 \mathrm{Ma}$ with sporadic eruptions of alkaline basaltic magmas (Embey-Isztin et al., 1993) and formation of a huge trachyandesite volcano in the western part of the Pannonian Basin (Fig. 2A; Harangi et al., 1995a; Harangi, 2001b). This alkaline volcanic activity occurred during the late stage of the synrift phase and may have been a direct consequence of thinning of the lithosphere and the passive upwelling of hot asthenosphere. However, it is remarkable that this mafic volcanism took place mostly at the western periphery of the Pannonian Basin (Burgenland; Fig. 2B) and not in the regions that underwent significant thinning. Chemical composition of these mafic magmas (group 1 basalts in Fig. 5G) indicates that the melt generation occurred in the garnet-peridotite stability zone, i.e., $>80 \mathrm{~km}$ depth by $2 \%-4 \%$ of melting (Fig. 12; Embey-Isztin et al., 1993; Embey-Isztin and Dobosi, 1995; Harangi, 2001b). Harangi (2001b) compared the major-element data, normalized to $\mathrm{MgO}=15 \mathrm{wt} \%$, with experimental data and concluded that the melt generation could occur at $110-125 \mathrm{~km}$ depth. The present thickness of the lithosphere beneath this region is $110-120 \mathrm{~km}$; therefore, the source region of these mafic magmas could have been at about the lithosphereasthenosphere boundary, presumably in the uppermost asthenosphere. Enrichment of incompatible trace elements and the negative $\mathrm{K}$ anomaly in the primitive mantle-normalized traceelement patterns (Fig. 5G) suggest an enriched source region with a K-bearing phase in the residue. This K-bearing phase could be phlogopite or amphibole. Partial melting model calculations indicate that small-degree (max. $1 \%-2 \%$ ) melting of garnet peridotite with $4 \%$ amphibole or $2.5 \%$ phlogopite and an enriched chemical composition ( $1.5-3$ times primitive mantle composition) explain well the trace-element pattern of the $11 \mathrm{Ma}$ alkaline basalts. The presumed depth of melt generation ( $>25-30 \mathrm{kbar}$, $>100 \mathrm{~km})$ and the depletion in $\mathrm{Rb}$ favor phlogopite in the residuum. The alkaline basalts in the western CarpathianPannonian region have a relatively high ${ }^{206} \mathrm{~Pb} / 204 \mathrm{~Pb}$ isotope ratio (19.7-19.8; Fig. 6; Embey-Isztin et al., 1993; Rosenbaum et al., 1997), suggesting a HIMU-like character.

The thick lithosphere beneath the location of the $11 \mathrm{Ma}$ alkaline mafic volcanism does not appear to support a direct relationship between melt generation and extension of the Pannonian

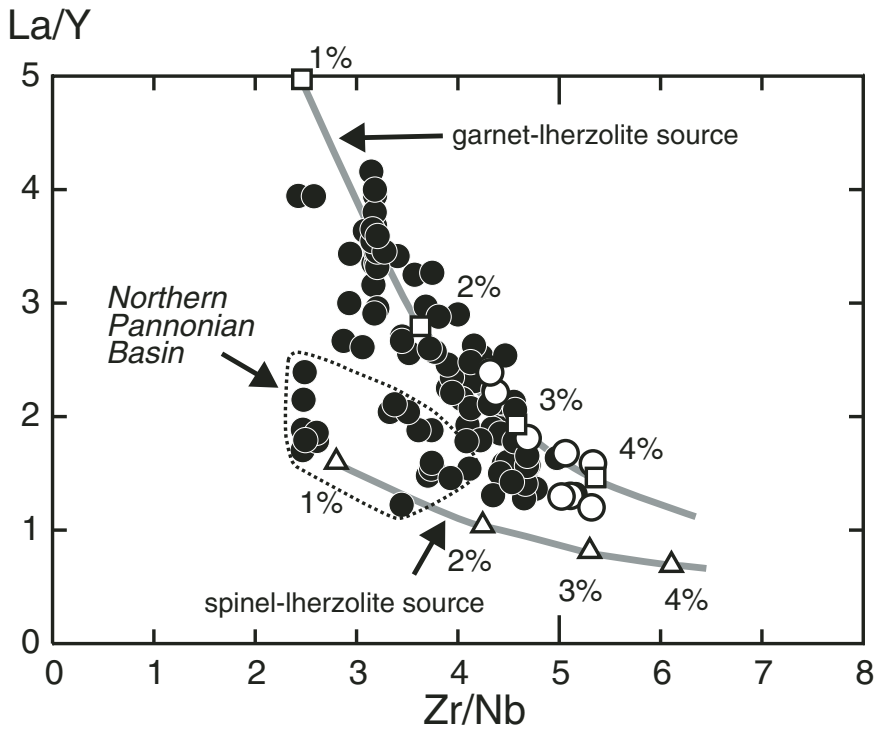

Figure 12. Petrogenetic model calculation for the genesis of the late Miocene to Quaternary alkaline mafic magmas with $>7 \mathrm{wt} \% \mathrm{MgO}$ in the Carpathian-Pannonian region (open circles denote the $11 \mathrm{Ma}$ basalts). Model parameters: nonmodal equilibrium partial melting process with the following source rocks: spinel-lherzolite-olivine $(57 \%)$, orthopyroxene $(25.5 \%)$, clinopyroxene $(15 \%)$, spinel $(2.5 \%)$; garnet-lherzolite - olivine $(60.1 \%)$, orthopyroxene (18.9\%), clinopyroxene (13.7\%), garnet (7.3\%). Melting modes: are $\mathrm{ol}_{1.21} \mathrm{opx} \mathrm{px}_{8.06} \mathrm{cpx}_{76.37}$ $\mathrm{sp}_{14.36}$ and $\mathrm{ol}_{1.3} \mathrm{opx}_{8.7} \mathrm{cpx}_{36} \mathrm{gt}_{54}$. Source rocks composition: $\mathrm{La}$ and $\mathrm{Nb}-$ $4 \times$ primitive mantle values ( 2.59 and $2.63 \mathrm{ppm}$, respectively), $\mathrm{Zr}$ $2 \times$ primitive mantle values $(21 \mathrm{ppm})$, and $\mathrm{Y}-1.5 \times$ primitive mantle values (6.45 ppm). Distribution coefficients are from Kostopoulos and James (1992).

Basin. Furthermore, it is remarkable that this mafic volcanism was roughly coeval with the major change (from high $\mathrm{La} / \mathrm{Nb}$ to low $\mathrm{La} / \mathrm{Nb}$ ) in the composition of the calc-alkaline volcanic suite from the northern Pannonian Basin (Fig. 7). If extension did not play a major role in the melt generation process, we may infer that hot asthenospheric mantle could have arrived beneath the thinning Carpathian-Pannonian region and provided heat to melt the metasomatized portion of the lithospheric mantle or underwent partial melting just below the continental lithosphere. One of the possibilities is the deflection of the presumed mantle plume beneath the Bohemian massif (Wilson and Patterson, 2001) due to the suction effect of backarc rifting and detachment of the subducted slab at the northern part of the Carpathian-Pannonian region (Harangi et al., 2006).

\section{Role of a Mantle Plume}

The main phase of the alkaline mafic volcanism started at $7 \mathrm{Ma}$ and culminated at 2-4 Ma, resulting in monogenetic volcanic fields sporadically distributed in the Carpathian-Pannonian region (Fig. 2A). This volcanism occurred more than 5 m.y. after the cessation of the synrift phase of the Pannonian Basin (Fig. 3); therefore, the thinning of lithosphere could not be the direct rea- 
son for the melt generation. The alkaline basalts have a high Mgnumber $(>0.62)$ and often contain ultramafic xenoliths, suggesting only a small degree of magma differentiation and fast ascent of the magmas from their mantle source regions (Embey-Isztin et al., 1993, 2001; Embey-Isztin and Dobosi, 1995; Harangi et al., 1995a; Harangi, 2001b). The trace-element data, particularly the heavy REE concentrations (Figs. 5G and 5H), suggest that garnet should be present as a residual phase during melting and the source region should be enriched in incompatible trace elements (Embey-Isztin et al., 1993; Harangi et al. 1995a; Harangi, 2001b; Seghedi et al., 2004b). The nonmodal batch partial melting calculation shows that most of the mafic magmas could originate by $1.5 \%-4 \%$ melting in the garnet-peridotite depth (Fig. 12), i.e., deeper than $80 \mathrm{~km}$. The alkaline basalts in the northern Pannonian Basin (Stiavnica-Nógrád-Gemer volcanic field; Fig. 2B) deviate, however, from this melting trend and can be explained either by generation at shallower depth, i.e., in the spinel-garnet peridotite field (60-80 km depth interval), or from a more-enriched (lower $\mathrm{Zr} / \mathrm{Nb}$ ) source region. The present thickness of the lithosphere beneath the Pannonian Basin is $60-80 \mathrm{~km}$ (Tari et al., 1999), implying that the partial melting process could take place just beneath the continental lithosphere.

In the Little Hungarian Plain, alkaline mafic volcanism took place at ca. $5 \mathrm{Ma}$ (Balogh et al., 1986), leading to development of small-volume basaltic volcanoes in an $\sim 6 \times 10 \mathrm{~km}$ area (Harangi et al., 1995a). Here, the basaltic rocks show large compositional variation, covering almost the whole geochemical range of the alkaline mafic rocks in the Pannonian Basin (Fig. 13). Since all these basaltic rocks have high Mg-numbers (>0.62), are silicaundersaturated in variable degrees, and some of them contain mantle xenoliths, major crystal fractionation and significant crustal contamination can be excluded in their genesis. Thus, variation in their compositions can be used to constrain the nature of their mantle sources and/or the melting condition. The negative $\mathrm{K}$ anomaly in the basanites indicates phlogopite and/or amphibole in the residuum. The trachybasalts do not show this feature (group 2 basalts in Fig. $5 \mathrm{H}$ ), which can be explained by a higher degree of melting consuming the hydrous minerals of the same mantle source. However, these basalts have significantly different strongly incompatible trace-element ratios as well as $\mathrm{Sr}-\mathrm{Nd}$ isotope ratios compared with the basanites (Harangi et al., 1995a; Harangi, 2001b), implying a distinct mantle source. Nevertheless, as we discussed before, all of these basaltic magmas were probably generated in the garnet-peridotite field, i.e., in the asthenosphere. Thus, we can conclude that the asthenosphere is chemically heterogeneous, presumably in a relatively small scale, beneath the western Carpathian-Pannonian region.

In addition to the alkaline basalts, leucitite and latite magmas were formed in the southern Carpathian-Pannonian region at 1.5-2 Ma (Fig. 2A; Harangi et al., 1995b; Seghedi et al., 2004a). The source region of these magmas could be in the lithospheric mantle. The basaltic and the young potassic magmatism cannot be directly related to lithospheric extension, since it postdates the synrift phase. Thus, partial melting either in the continental lithosphere or in the asthenosphere requires an increase of temperature. The only mechanism that is able to provide extra heat is mantle flow. The chemical compositions of the alkaline mafic rocks show many similarities with the Neogene to Quaternary alkaline basalts from Western and Central Europe (Wilson and Downes, 1991; Embey-Isztin et al., 1993). In the mid-1990s, integrated geochemical and seismic studies led to the proposition that localized mantle upwellings ("mantle plume fingers"

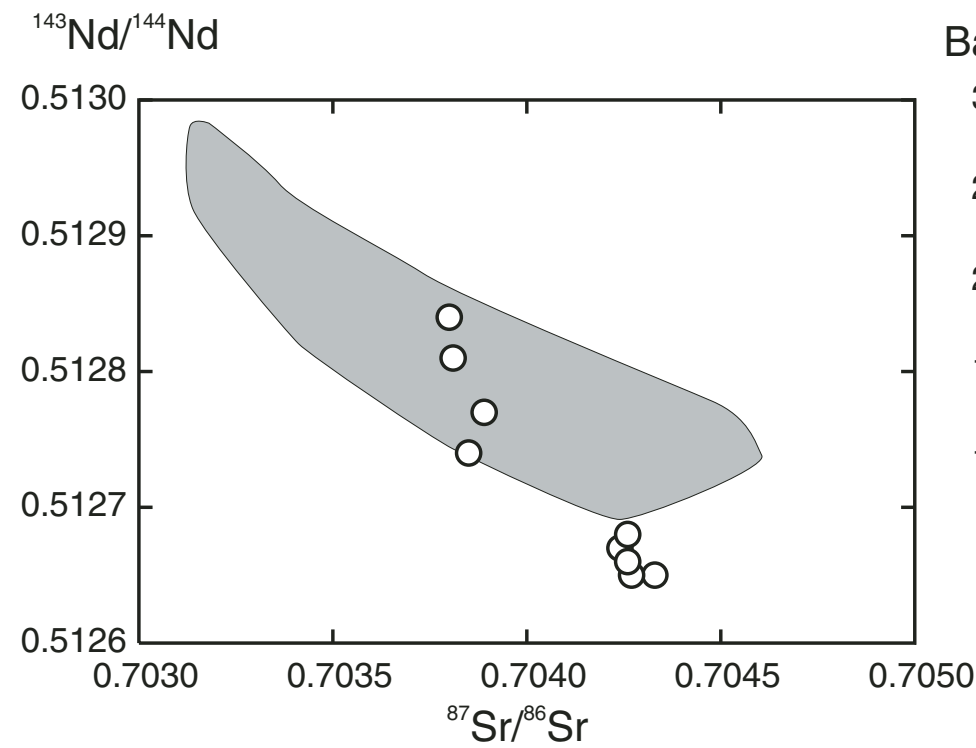

\section{$\mathrm{Ba} / \mathrm{Nb}$}

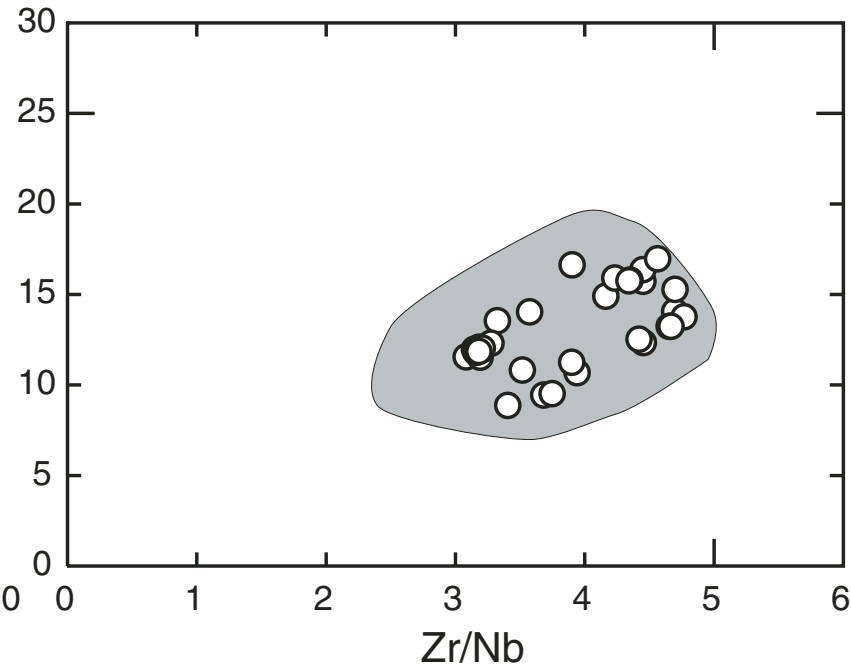

Figure 13. Variation of isotopic and trace-element ratios in the alkaline mafic rocks $(>7 \% \mathrm{MgO})$ occurring in a $6 \times 10 \mathrm{~km}$ area of the Little Hungarian Plain. For comparison, the geochemical variation of the mafic rocks from the Carpathian-Pannonian region is also shown. This relatively large compositional variation in the near-primitive 5 Ma mafic magmas implies partial melting of a heterogeneous mantle. 
or "baby-plumes") that were derived from a common mantle reservoir ("European asthenospheric reservoir" = EAR; Cebriá and Wilson, 1995) could be responsible for the volcanism in the Massif Central, the Rhenish area, the Eger graben, Bohemia, and also in the Pannonian Basin (Hoernle et al., 1995; Granet et al., 1995). The European asthenospheric reservoir component of these plume fingers is characterized by a HIMU- (or Focal Zone [FOZO])-like (more precisely a mixture of HIMU and depleted mantle components) isotopic composition. It has been suggested that the European asthenospheric reservoir-like magmas subsequently interacted with the local lithospheric mantle, resulting in a compositional shift toward different enriched components (Hoernle et al., 1995). Upwelling of a localized mantle plume beneath the Pannonian Basin can readily explain the melt generation and volcanism after the peak extension in the middle Miocene (Seghedi et al., 2004a).

Goes et al. (1999) and Buikin et al. (2005) suggested that the scattered mantle plumes beneath Central and Western Europe could have a common origin in the lower mantle. Remarkably, the alkaline mafic volcanic fields in Europe are at the periphery of the Alpine-Mediterranean region, which is underlain by a positive seismic velocity anomaly in the depth range of 400-650 km (Fig. 1; Wortel and Spakman, 2000; Piromallo et al., 2001; Piromallo and Morelli, 2003). The high-velocity anomaly has been interpreted as accumulation of thick, cold material, possibly subducted residual material. This can form a barrier against the rise of the lower mantle plume and could separate it into several smaller branches ("mantle plume fingers"), which emerge at the periphery of the cold material. The geographic distribution of the alkaline mafic volcanic fields in Europe (Fig. 1) appears to support this model.

The Carpathian-Pannonian region is also underlain by the high-velocity body in the mantle transitional zone (Fig. 1; Wortel and Spakman, 2000). Thus, a hot mantle plume or a plume finger cannot be expected from the relatively "cold" base of the upper mantle. The characteristic features of the mantle plumes are also missing beneath this region. The broad topographic updoming, such as that detected in the Massif Central (Wilson and Patterson, 2001), or in classic hot spot areas (Courtillot et al., 2003), is absent; on the contrary, some parts of the Pannonian Basin are still subsiding. Two observations support the plume theory in the Carpathian-Pannonian region: the high heat flow in the region (Lenkey et al., 2002) and the HIMU-type signature of most of the alkaline basaltic rocks (Embey-Isztin and Dobosi, 1995). However, the high heat flow can be readily explained by the thinning of the lithosphere during basin formation and the still-shallow asthenosphere (Royden et al., 1983). Although many authors consider that the HIMU/FOZO-type isotopic ratios indicate a mantle plume, there are strong arguments for a metasomatic origin too (e.g., Hart, 1988; Sun and McDonough, 1989; Halliday et al., 1995; Pilet et al., 2005). In addition, the alkaline mafic volcanism in the CarpathianPannonian region has been sporadic, covering almost the whole region (Fig. 2A), and has had a fairly low magma production rate, which is inconsistent with the plume theory.
In summary, we can conclude that the presence of a mantle plume beneath the Pannonian Basin is highly unlikely. Thus, if we exclude the lithospheric extension-related melt generation and the mantle plume-related magma generation, how can we explain the formation of mafic magmas in this area from the late Miocene to the Quaternary? In addition, how were the 1.5-2 Ma leucitite and shoshonite generated? Eruption of alkali basalts has occurred even within the last 600 k.y. in the Carpathian-Pannonian region; the last volcanic eruption is represented by the 130 ka Putikov volcano in central Slovakia (Simon and Halouzka, 1996). Thus, the mantle beneath the Carpathian-Pannonian region appears to be still capable of melting!

This is not surprising, however, because due to the earlier thinning of the lithosphere, the temperature of the upper mantle might be still very close to the melting temperature, since the decay of a thermal anomaly caused by lithospheric thinning takes $\sim 100$ m.y. (e.g., McKenzie, 1978). The alkali basaltic volcanism started at $11 \mathrm{Ma}$, whereas the calc-alkaline volcanic activity in the northern Pannonian Basin changed to eruption of transitionaltype magmas at 9-10 Ma, just at the latest phase of the rifting phase. The subsequent $\sim 5-6 \mathrm{~m}$.y. volcanic quiescence in the western and central parts of the Carpathian-Pannonian region is coeval with a compressional phase in the whole area (Csontos et al., 1991; Peresson and Decker, 1997), lasting between $9 \mathrm{Ma}$ and 5.3 Ma (Peresson and Decker, 1997) or between $10 \mathrm{Ma}$ and $7 \mathrm{Ma}$ (Fodor et al., 1999). Nevertheless, 5-10 m.y. after the end of extension, the temperature in the lithosphere was still high enough to generate melt due to some local temperature perturbation. The reason for this temperature perturbation can only be flow in the mantle, but a large-scale mantle plume is not likely. The reason of the mantle flow is unclear (irregular shape of the lithosphere-asthenosphere boundary?); however, it might be only a local process and not as large one as Konečný et al. (2002) postulated.

\section{A Model for Melt Generation in the Carpathian- Pannonian Region for the Last 20 m.y.}

The Neogene volcanic activity in the CarpathianPannonian region is closely related to the tectonic evolution of the area. During Cretaceous and Paleogene time, subduction of oceanic lithosphere did not result in the direct production of calc-alkaline volcanism due to the overall compressive stress field and the presence of a thick crust and lithosphere. Nevertheless, this process played an important role in the generation of magmas. Dehydration of the descending slab metasomatized the mantle wedge, lowering the melting temperature. Magmas reached the surface only at the beginning of lithospheric stretching, which was initiated first by northeastward translation and rotation of the North Pannonian block and juxtaposition with the Tisza microplate during the early Miocene (19-21 Ma). Mantle-derived magmas intruded into the crustmantle boundary zone, causing extensive melting in the lower crust. These mixed magmas evolved to Si-rich rhyolitic liquids, 
which erupted mostly along the weak shear zone between the two microplates. The retreating subduction resulted in further extension in the backarc area, which initiated magmatism closer to the suture zone in the northern Pannonian Basin during the middle Miocene (ca. $16 \mathrm{Ma}$ ). Melt generation occurred in the passively upwelling metasomatized upper mantle, and, then, these magmas mixed with metasedimentary lower-crustal melts. In the hydrous, Al-saturated silicate liquids, almandine garnets could crystallize at high pressure, and the tensional stress field enabled the rapid ascent of these magmas along major faults at the northern Pannonian Basin. The gradual compositional change (e.g., decreasing ${ }^{87} \mathrm{Sr} /{ }^{86} \mathrm{Sr}$ isotope ratio, $\mathrm{La} / \mathrm{Nb}$ and $\mathrm{Th} / \mathrm{Nb}$ ratios) both in the calc-alkaline and in the silicic suites implies a decreasing role of the crustal component. This is consistent with magmatism in a continuously thinning continental plate. The direct control on the melt generation could be lithospheric extension, causing decompression melting of the ascending upper mantle. The still-ongoing subduction at depth could help this process, providing aqueous fluids for the overlying mantle and initiating mantle flow by the rollback process and gravitational sinking of the dense slab fragments.

In the northern Pannonian Basin, the 16-9 Ma calc-alkaline suite shows a two-component mixing trend in the ${ }^{206} \mathrm{~Pb} /{ }^{204} \mathrm{~Pb}$ versus ${ }^{87} \mathrm{Sr} /{ }^{86} \mathrm{Sr}$ isotope diagram (Fig. 8), similar to other areas of the Mediterranean region (e.g., central Italy, Peccerillo, 2003; SE-Spain, Duggen et al., 2005). The mantle end member of this mixing trend is characterized by a relatively high ${ }^{206} \mathrm{~Pb} /{ }^{204} \mathrm{~Pb}$ ratio, which resembles the isotopic composition of most of the circum-Mediterranean alkaline mafic rocks (Wilson and Patterson, 2001). Such HIMU/FOZO-like magmas also occur within the Mediterranean region, and this feature has been interpreted to represent the involvement of a deep mantle plume, either channeled through a slab window (Gasperini et al., 2002) or as an active upwelling beneath the opening Tyrrhenian Basin (Bell et al., 2004). On the contrary, Peccerillo and Lustrino (2005) argued against the presence of any mantle plumes beneath the Central Mediterranean.

In the Carpathian-Pannonian region, magmas with a HIMU/ FOZO-like composition erupted at 10-11 Ma (alkali basalts at Burgenland, western part of the Carpathian-Pannonian region, Embey-Isztin et al., 1993; Rosenbaum et al., 1997, Harangi, 2001b; and transitional basalts and basaltic andesites in the northern Pannonian Basin, Harangi, 2001a). This magmatism could be attributable to the latest stage of lithospheric extension, when upwelling, enriched asthenosphere underwent low-degree partial melting, leaving garnet and a potassic hydrous phase, presumably phlogopite, in the residuum. This magmatism was confined to the northwestern and northern part of the Pannonian Basin, where subduction ceased just a couple of million years before. Detachment and gravitational sinking of the dense slabs into the deeper mantle could have resulted in convective instabilities and change in the mantle flow within the shallow mantle, which would have enhanced upwelling of nonmetasomatized, relatively hot, enriched mantle material (Konečný et al., 2002).
In the inner part of the Pannonian Basin, far from the subduction zone, the lithospheric extension caused localized melting in the metasomatized continental lithosphere and eruption of potassic and ultrapotassic magmas. Major block rotation and associated extension in the Apuseni Mountains were associated with calc-alkaline volcanism from 15 to $9 \mathrm{Ma}$ (Seghedi et al., 2004a). In the eastern part of the Carpathian-Pannonian region, subduction of the oceanic plate ceased gradually from $13 \mathrm{Ma}$ to $10 \mathrm{Ma}$. The calc-alkaline volcanism spatially fairly close to the suture zone was mostly postcollisional and is inferred to have been related to a slab break-off process (Mason et al., 1998; Nemčok et al., 1998; Seghedi et al., 1998, 2001). This is supported by the gradual southeastward younging of the volcanic eruptions, the short-lived volcanism at the individual volcanic centers, and the uplift history of the Carpathians.

In the Pannonian Basin, the alkaline basaltic volcanism began at the end of rifting (11 Ma), had a quiescence period during a regional compressional event (Peresson and Decker, 1997; Fodor et al., 1999) from $10 \mathrm{Ma}$ to ca. 7-5 Ma, and later continued until recently. Thus, lithospheric extension could not have played a direct role in the magma generation for the last 5 m.y. However, the mantle potential temperature beneath the thin lithosphere may still remain close to the solidus temperature, and local perturbation caused by mantle flow may still result in low-degree partial melting within the asthenosphere. Based on geophysical and geological observations (e.g., presence of a high-velocity anomaly, i.e., a presumably cold body of accumulated material at the base of the upper mantle beneath the Pannonian Basin; Wortel and Spakman, 2000, Piromallo et al., 2001; absence of regional doming, but rather still ongoing subsidence in many parts of the Pannonian Basin; scattered basaltic volcanism with low magma production rate, etc.), we rule out a mantle plume beneath the Pannonian Basin.

The alkaline mafic magmas show a relatively wide compositional variation, both regionally and locally. This compositional variation and the presence of the HIMU/FOZO-like isotope and trace-element ratios can be explained by a heterogeneous mantle model (Helffrich and Wood, 2001), such as a marble-cake or a streaky mantle model (Allégre and Turcotte, 1986; Smith, 2005). The shallow asthenospheric mantle could be heterogeneous on a relatively small-scale, preserving fragments of subducted crust for a long time (Meibom and Anderson, 2004; Kogiso et al., 2004). Niu and O'Hara (2003) suggested that metasomatized oceanic lithospheric portions could be important geochemical reservoirs hosting volatiles and trace-element and isotopic characteristics resulting from former metasomatism. The long history of orogenic events (Hercynian and Alpine orogenesis) in Europe could supply vast amount of crustal material into the upper mantle, resulting in geochemical heterogeneity on various scales. Partial melting of different parts of the shallow asthenospheric mantle (metasomatized, phlogopite-bearing enriched sections with HIMU-like composition and depleted mid-ocean-ridge basalt [MORB] mantle around them) and mixing of these melts could also explain the compositional variation in the alkaline 
Harangi and Lenkey

mafic magmas of the Pannonian Basin. Furthermore, this model explains also the occurrence of HIMU/FOZO- or European asthenospheric reservoir-like magmas even during the EoceneOligocene (Macera et al., 2003; Cvetkovic et al., 2004) and during the Cretaceous (Harangi, 1994; Dostal and Owen, 1998; Harangi et al., 2003) in Europe. The relatively high surface heat flow (Lenkey et al., 2002) and the fairly recent ( $<500 \mathrm{ka})$ mafic volcanism in the northern part of the Pannonian Basin suggest that the mantle is potentially still capable of producing basaltic magma, which could reach the surface if the actual stress field allows it.

In the postcollisional calc-alkaline volcanism along the eastern part of the Carpathian-Pannonian region, a significant change occurred at $3 \mathrm{Ma}$. The erupted magmas in the southeastern Carpathians, close to the Vrancea zone, are characterized by an increase of potassium and high abundance of barium and strontium. Mason et al. (1998) and Seghedi et al. (2004a) proposed formation of a shallow $(<50 \mathrm{~km})$ slab window and slab melting under a volatile-rich condition (extensive dehydration of the descending slab). However, boron (B), a fluid-mobile trace element, decreases significantly in these volcanic rocks compared with the 3-6 Ma calc-alkaline andesites to the north, a feature that does not support the increasing release of aqueous fluids beneath this area. Furthermore, geophysical observations (Wortel and Spakman, 2000; Sperner et al., 2001, 2004) do not support the presence of a slab window beneath the Vrancea zone. Significantly, the compositional change in the erupted magmas corresponds to a major lithosphere-scale fault (Trotus fault), which separates two different continental blocks (Cloetingh et al., 2004). In this context, the most recent volcanism (eruption of high-K dacite magmas at Ciomadul as recent as 20-30 ka and alkali basalt magmas at Persany) could be closely associated with the deep processes occurring beneath the Vrancea zone. The intermediate-depth earthquakes suggest that this is a still active system. Delamination of the lower lithosphere inducing upwelling of hot asthenospheric mantle (Doglioni, 1993; Gîrbacea and Frisch, 1998; Chalot-Prat and Gîrbacea, 2000) seems to be a plausible scenario for the melt generation that results in alkaline basaltic melts by decompression melting of the uprising asthenosphere and potassic magmas by melting of the lower continental lithosphere due to the heat flux of the shallow asthenosphere. Further investigations are crucial to have a better understanding of the magma generation process in this area and the relationship with the intermediate-depth seismic events.

The Carpathian-Pannonian region has been characterized by a relatively long volcanic history since the early Miocene. The volcanism appears to have been in a waning phase for the last 2 m.y., but the quite recent volcanic eruptions (e.g., development of an alkaline basaltic scoria cone with a lava flow in the northern Pannonian Basin at $150 \mathrm{ka}$, Simon and Halouzka, 1996; explosive volcanic eruption of the Ciomadul volcano at 20-30 ka, Juvigne et al., 1994; Moriya et al., 1996; Vinkler et al., 2007) suggest that conditions in the shallow mantle could still enable melt generation and volcanic eruption in the future.

\section{ACKNOWLEDGMENTS}

The ideas presented in this paper are the result of many discussions with a number of colleagues of the Pannonian Basin-Carpathians-Dinarides (PANCARDI) Igneous Team, especially Hilary Downes, Alex Szakács, Nino Seghedi, Paul Mason, Orlando Vaselli, and Csaba Szabó during the last decade. S. Harangi is especially grateful to Hilary Downes for the continuous encouragement during his work. Critical comments provided by Paul Mason and Ioan Seghedi helped us to clarify our ideas, which, however, still deviate partly from the reviewers' views. We thank also for the patient editorial help of Gianluca Bianchini. This work was partially supported by the Hungarian Research Foundation (OTKA) grant T037974 to Harangi.

\section{REFERENCES CITED}

Allégre, C., and Turcotte, D.L., 1986, Implications of a two-component marblecake mantle: Nature, v. 323, p. 123-127, doi: 10.1038/323123a0.

Bada, G., and Horváth, F., 2001, On the structure and tectonic of the Pannonian Basin and surrounding orogens: Acta Geologica Hungarica, v. 44 , p. 301-327.

Balla, Z., 1981, Neogene volcanism of the Carpatho-Pannonian region: Earth Evolution Science, v. 3-4, p. 240-248.

Balla, Z., 1986, Paleotectonic reconstruction of the central Alpine-Mediterranean belt for the Neogene: Tectonophysics, v. 127, p. 213-243, doi: 10.1016/0040-1951(86)90062-4.

Balla, Z., 1988, Clockwise paleomagnetic rotations in the Alps in the light of the structural pattern of the Transdanubian Range (Hungary): Tectonophysics, v. 145, p. 277-292, doi: 10.1016/0040-1951(88)90200-4.

Balogh, K., Árva-Sós, E., and Pécskay, Z., 1986, K/Ar dating of post Sarmatian alkali basaltic rocks in Hungary: Acta Mineralogie et Petrographie Szeged, v. 28, p. 75-93.

Behrmann, J.H., Staisny, S., Milicka, J., and Pereszlenyi, M., 2000, Quantitative reconstruction of orogenic convergence in the northeast Carpathians: Tectonophysics, v. 319, p. 111-128, doi: 10.1016/S0040-1951(00)00020-2.

Bell, K., Castorina, F., Lavecchia, G., Rosatelli, G., and Stoppa, F., 2004, Is there a mantle plume below Italy?: Eos (Transactions, American Geophysical Union), v. 85, p. 541-547.

Bleahu, M., Boccaletti, M., Manetti, P., and Peltz, S., 1973, The Carpathian arc: A continental arc displaying the features of an 'island arc': Journal of Geophysical Research, v. 78, p. 5025-5032.

Brousse, R., Bizouard, H., and Salát, J., 1972, Grenats des andésites et des rhyolites de Slovaquie, origine des grenats dans les séries andésitiques: Contributions to Mineralogy and Petrology, v. 35, p. 201-213, doi: 10.1007/BF00371215.

Buikin, A., Trieloff, M., Hopp, J., Althaus, T., Korochantseva, E., Schwarz, W.H., and Altherr, R., 2005, Noble gas isotopes suggest deep mantle plume source of late Cenozoic mafic alkaline volcanism in Europe: Earth and Planetary Science Letters, v. 230, p. 143-162, doi: 10.1016/ j.eps1.2004.11.001.

Cebriá, J.M., and Wilson, M., 1995, Cenozoic mafic magmatism in westerncentral Europe: A common European asthenospheric reservoir?: Terra Nova, v. 7, p. 162.

Chalot-Prat, F., and Gîrbacea, R., 2000, Partial delamination of continental mantle lithosphere, uplift-related crust-mantle decoupling, volcanism and basin formation: A new model for the Pliocene-Quaternary evolution of the southern East-Carpathians, Romania: Tectonophysics, v. 327, p. 83 107, doi: 10.1016/S0040-1951(00)00155-4.

Cloetingh, S.A.P.L., Burov, E., Matenco, L., Toussaint, G., Bertotti, G., Andriessen, P.A.M., Wortel, M.J.R., and Spakman, W., 2004, Thermomechanical controls on the mode of continental collision in the SE Carpathians (Romania): Earth and Planetary Science Letters, v. 218, p. $57-$ 76, doi: 10.1016/S0012-821X(03)00645-9.

Courtillot, V., Davaille, A., Besse, J., and Stock, J., 2003, Three distinct types of hotspots in the Earth's mantle: Earth and Planetary Science Letters, v. 205, p. 295-308, doi: 10.1016/S0012-821X(02)01048-8. 
Csontos, L., 1995, Tertiary tectonic evolution of the Intra-Carpathian area: A review, in Downes, H., and Vaselli, O., eds., Neogene and Related Magmatism in the Carpatho-Pannonian Region: Acta Vulcanologica, v. 7, p. 1-13.

Csontos, L., Tari, G., Bergerat, F., and Fodor, L., 1991, Structural evolution of the Carpatho-Pannonian area during the Neogene: Tectonophysics, v. 199, p. 73-91, doi: 10.1016/0040-1951(91)90119-D.

Csontos, L., Nagymarosy, A., Horváth, F., and Kovác, M., 1992, Tertiary evolution of the Intra-Carpathian area: A model: Tectonophysics, v. 208, p. 221-241, doi: 10.1016/0040-1951(92)90346-8.

Cvetkovic, V., Prelevic, D., Downes, H., Jovanovic, M., Vaselli, O., and Pecskay, Z., 2004, Origin and geodynamic significance of Tertiary postcollisional basaltic magmatism in Serbia (central Balkan Peninsula): Lithos, v. 73, p. 161-186, doi: 10.1016/j.lithos.2003.12.004

Dobosi, G., Fodor, R.V., and Goldberg, S.A., 1995, Late-Cenozoic alkali basalt magmatism in Northern Hungary and Slovakia: Petrology, source compositions and relationship to tectonics, in Downes, H., and Vaselli, O., eds., Neogene and Related Magmatism in the Carpatho-Pannonian Region: Acta Vulcanologica, v. 7, p. 199-207.

Doglioni, C., 1993, Comparison of subduction zones versus the global tectonic pattern: A possible explanation for the Alps-Carpathians system: Geophysical Transactions, v. 37, p. 253-264.

Dostal, J., and Owen, J.V., 1998, Cretaceous alkaline lamprophyres from northeastern Czech Republic: Geochemistry and petrogenesis: Geologische Rundschau, v. 87, p. 67-77, doi: 10.1007/s005310050190.

Downes, H., Pantó, G., Póka, T., Mattey, D., and Greenwood, B., 1995a, Calcalkaline volcanics of the Inner Carpathian arc, Northern Hungary: New geochemical and oxygen isotopic results, in Downes, H., and Vaselli, O., eds., Neogene and Related Magmatism in the Carpatho-Pannonian Region: Acta Vulcanologica, v. 7, p. 29-41.

Downes, H., Seghedi, I., Szakacs, A., Dobosi, G., James, D.E., Vaselli, O., Rigby, I.J., Ingram, G.A., Rex, D., and Pecskay, Z., 1995b, Petrology and geochemistry of late Tertiary/Quaternary mafic alkaline volcanism in Romania: Lithos, v. 35, p. 65-81, doi: 10.1016/0024-4937(95)91152-Y.

Duggen, S., Hoernle, K., van den Bogaard, P., and Garbe-Schonberg, D., 2005, Post-collisional transition from subduction- to intraplate-type magmatism in the westernmost Mediterranean: Evidence for continental-edge delamination of subcontinental lithosphere: Journal of Petrology, v. 46, p. 1155-1201, doi: 10.1093/petrology/egi013.

Elliott, T., Plank, T., Zindler, A., White, W., and Bourdon, B., 1997, Element transport from slab to volcanic front at the Mariana arc: Journal of Geophysical Research, v. 102, p. 14,991-15,019.

Embey-Isztin, A., and Dobosi, G., 1995, Mantle source characteristics for Miocene-Pleistocene alkali basalts, Carpathian-Pannonian region: A review of trace elements and isotopic composition, in Downes, H., and Vaselli, O., eds., Neogene and Related Magmatism in the CarpathoPannonian Region: Acta Vulcanologica, v. 7, p. 155-166.

Embey-Isztin, A., Noske-Fazekas, G., Kurat, G., and Brandstätter, F., 1985, Genesis of garnets in some magmatic rocks from Hungary: Tschermak Mineralogische Petrographische Mitteilungen, v. 34, p. 49-66, doi: 10.1007/BF01082457.

Embey-Isztin, A., Downes, H., James, D.E., Upton, B.G.J., Dobosi, G., Ingram, G.A., Harmon, R.S., and Scharbert, H.G., 1993, The petrogenesis of Pliocene alkaline volcanic rocks from the Pannonian Basin, Eastern Central Europe: Journal of Petrology, v. 34, p. 317-343.

Embey-Isztin, A., Downes, H., and Dobosi, G., 2001, Geochemical characterization of the Pannonian Basin mantle lithosphere and asthenosphere: an overview: Acta Geologica Hungarica, v. 44, p. 259-280.

Embey-Isztin, A., Downes, H., Kempton, P.D., Dobosi, G., and Thirlwall, M.F., 2003, Lower crustal granulite xenoliths from the Pannonian Basin, Hungary. Part 1: Mineral chemistry, thermobarometry and petrology: Contributions to Mineralogy and Petrology, v. 144, p. 652-670.

Fan, G., Wallace, T.C., and Zhao, D., 1998, Tomographic imaging of deep velocity structure beneath the Eastern and Southern Carpathians, Romania: Implications for continental collision: Journal of Geophysical Research, v. 103, p. 2705-2723, doi: 10.1029/97JB01511.

Fitton, J.G., 1972, The genetic significance of almandine-pyrope phenocrysts in the calc-alkaline Borrowdale volcanic group, northern England: Contributions to Mineralogy and Petrology, v. 36, p. 231-248, doi: 10.1007/ BF00371434.

Fitton, J.G., James, D., and Leeman, W.P., 1991, Basic magmatism associated with Late Cenozoic extension in the Western United States: composi- tional variations in space and time: Journal of Geophysical Research, v. 96, p. $13693-13711$.

Fodor, L., Csontos, L., Bada, G., Györfi, I., and Benkovics, L., 1999, Tertiary tectonic evolution of the Pannonian Basin system and neighbouring orogens: A new synthesis of palaeostress data, in Durand, B., Jolivet, L.F.H., and Séranne, M., eds., The Mediterranean Basins: Tertiary Extension within the Alpine Orogen: Geological Society of London Special Publication 156, p. 295-334.

Gallagher, K., and Hawkesworth, C.J., 1992, Dehydration melting and the generation of continental flood basalts: Nature, v. 358 , p. 57-59, doi: $10.1038 / 358057 \mathrm{a} 0$.

Gans, P.B., Mahood, G.A., and Schermer, E., 1989, Syn-extensional magmatism in the Basin and Range Province: A case study from the eastern Great Basin: Geological Society of America Special Paper 233, 53 p.

Gasperini, D., Blichert-Toft, J., Bosch, D., Del Moro, A., Macera, P., Telouk, P., and Albarede, F., 2002, Upwelling of deep mantle material through a plate window: Evidence from the geochemistry of Italian basaltic volcanism: Journal of Geophysical Research, v. 107, p. 2367-2371, doi: 10.1029/2001JB000418

Gilbert, J.S., and Rogers, N.W., 1989, The significance of garnet in the PermoCarboniferous volcanic rocks of the Pyrenees: Journal of the Geological Society of London, v. 146, p. 477-490.

Gill, J.B., 1981, Orogenic Andesites and Plate Tectonics: Berlin, Springer, $390 \mathrm{p}$.

Gill, J.B., Morris, J.D., and Johnson, R.W., 1993, Timescale for producing the geochemical signature of island arc magmas: U-Th-Po and Be-B systematics in recent Papua New Guinea lavas: Geochimica et Cosmochimica Acta, v. 57, p. 4269-4283, doi: 10.1016/0016-7037(93)90322-N.

Girbacea, R., and Frisch, W., 1998, Slab in the wrong place: Lower lithospheric mantle delamination in the last stage of Eastern Carpathians subduction retreat: Geology, v. 26, p. 611-614, doi: 10.1130/00917613(1998)026<0611:SITWPL $>2.3$. CO;2.

Gméling, K., Kasztovszky, Zs., Harangi, Sz., Szentmiklósi, L., and Révay, Zs., 2007, Geological use of prompt gamma activation analysis: Importance of the boron concentration in volcanic rocks: Journal of Radioanalytical and Nuclear Chemistry, v. 271 (in press).

Goes, S., Spakman, W., and Bijwaard, H., 1999, A lower mantle source for central European volcanism: Science, v. 286, p. 1928-1931, doi: 10.1126/ science.286.5446.1928

Granet, M., Wilson, M., and Achauer, U.L., 1995, Imaging a mantle plume beneath the French Massif Central: Earth and Planetary Science Letters, v. 136, p. 281-296.

Green, T.H., 1977, Garnet in silicic liquids and its possible use as a $P-T$ indicator: Contributions to Mineralogy and Petrology, v. 65, p. 59-67, doi: 10.1007/BF00373571

Green, T.H., 1992, Experimental phase equilibrium studies of garnet-bearing I-type volcanics and high-level intrusives from Northland, New Zealand: Transactions of the Royal Society of Edinburgh, Earth Sciences, v. 83, p. $429-438$

Gvirtzman, Z., 2002, Partial detachment of a lithospheric root under the southeast Carpathians: Toward a better definition of the detachment concept: Geology, v. 30, p. 51-54, doi: 10.1130/0091-7613(2002)030<0051 PDOALR $>2.0 . C O ; 2$.

Halliday, A.N., Lee, D.C., Tommasini, S., Davies, G.R., Paslick, C.R., Fitton, J.G., and James, D.E., 1995, Incompatible trace element in OIB and MORB source enrichment in the sub-oceanic mantle: Earth and Planetary Science Letters, v. 133, p. 379-395, doi: 10.1016/0012-821X(95)00097-V.

Harangi, S., 1994, Geochemistry and petrogenesis of the Early Cretaceous continental rift-type volcanic rocks of the Mecsek Mountains: South Hungary: Lithos, v. 33, p. 303-321.

Harangi, S., 2001a, Neogene to Quaternary volcanism of the Carpathian-Pannonian region-A review: Acta Geologica Hungarica, v. 44, p. 223-258.

Harangi, S., 2001b, Neogene magmatism in the Alpine-Pannonian transition zone-A model for melt generation in a complex geodynamic setting: Acta Vulcanologica, v. 13, p. 25-39.

Harangi, S., Vaselli, O., Tonarini, S., Szabó, C., Harangi, R., and Coradossi, N., 1995a, Petrogenesis of Neogene extension-related alkaline volcanic rocks of the Little Hungarian Plain volcanic field (western Hungary), in Downes, H., and Vaselli, O., eds., Neogene and Related Magmatism in the Carpatho-Pannonian Region: Acta Vulcanologica, v. 7, p. 173-187.

Harangi, S., Wilson, M., and Tonarini, S., 1995b, Petrogenesis of Neogene potassic volcanic rocks in the Pannonian Basin, in Downes, H., and 
Vaselli, O., eds., Neogene and Related Magmatism in the Carpatho-Pannonian Region: Acta Vulcanologica, v. 7, p. 125-134.

Harangi, S., Downes, H., Kósa, L., Szabó, C., Thirlwall, M.F., Mason, P.R.D., and Mattey, D., 2001, Almandine garnet in calc-alkaline volcanic rocks of the northern Pannonian Basin (Eastern-Central Europe): Geochemistry, petrogenesis and geodynamic implications: Journal of Petrology, v. 42, p. 1813-1843, doi: 10.1093/petrology/42.10.1813.

Harangi, S., Tonarini, S., Vaselli, O., and Manneti, P., 2003, Geochemistry and petrogenesis of Early Cretaceous alkaline igneous rocks in Central Europe: implications for a long-lived EAR-type mantle component beneath Europe: Acta Geologica Hungarica, v. 46, p. 77-94, doi: 10.1556/ AGeol.46.2003.1.6.

Harangi, S., Mason, P.R.D., and Lukács, R., 2005, Correlation and petrogenesis of silicic pyroclastic rocks in the northern Pannonian Basin, EasternCentral Europe: In situ trace element data of glass shards and mineral chemical constraints: Journal of Volcanology and Geothermal Research, v. 143, p. 237-257, doi: 10.1016/j.jvolgeores.2004.11.012.

Harangi, S., Downes, H., and Seghedi, I., 2006, Tertiary-Quaternary subduction processes and related magmatism in the Alpine-Mediterranean region, in Gee, D., and Stephenson, R., eds., European Lithosphere Dynamics: Geological Society of London Memoir 32, p. 167-190.

Hart, S.R., 1988, Heterogeneous mantle domains: Signatures, genesis and mixing chronologies: Earth and Planetary Science Letters, v. 90, p. 273-296, doi: 10.1016/0012-821X(88)90131-8.

Hauser, F., Raileanu, V., Fielitz, W., Bala, A., Prodehl, C., Polonic, G., and Schulze, A., 2001, VRANCEA99-The crustal structure beneath the southeastern Carpathians and the Moesian Platform from a seismic refraction profile in Romania: Tectonophysics, v. 340, p. 233-256, doi: 10.1016/S0040-1951(01)00195-0.

Hawkesworth, C.J., Gallagher, K., Hergt, J.M., and McDermott, F., 1993, Mantle and slab contributions in arc magmas: Annual Review of Earth and Planetary Sciences, v. 21, p. 175-204.

Hawkesworth, C., Turner, S., Gallagher, K., Hunter, A., Bradshaw, T., and Rogers, N., 1995, Calc-alkaline magmatism, lithospheric thinning and extension in the Basin and Range: Journal of Geophysical Research, v. 100 , p. 10,271-10,286, doi: 10.1029/94JB02508.

Helffrich, G.R., and Wood, B.J., 2001, The Earth's mantle: Nature, v. 412, p. 501-507, doi: $10.1038 / 35087500$.

Hoernle, K., Zhang, Y.S., and Graham, D., 1995, Seismic and geochemical evidence for large-scale mantle upwelling beneath the eastern Atlantic and western and central Europe: Nature, v. 374, p. 34-39, doi: $10.1038 / 374034 \mathrm{a} 0$.

Horváth, F., 1993, Towards a mechanical model for the formation of the Pannonian Basin: Tectonophysics, v. 226, p. 333-357, doi: 10.1016/00401951(93)90126-5.

Horváth, F., 1995, Phases of compression during the evolution of the Pannonian Basin and its bearing on hydrocarbon exploration: Marine and Petroleum Geology, v. 12, p. 837-844, doi: 10.1016/0264-8172(95)98851-U.

Horváth, F., and Berckhemer, H., 1982, Mediterranean back arc basins, in Berckhemer, H., and Hsü, K., eds., Alpine-Mediterranean Geodynamics: American Geophysical Union and Geological Society of America, Geodynamic Series, v. 7, p. 141-173.

Horváth, F., and Cloething, S., 1996, Stress-induced late-stage subsidence anomalies in the Pannonian Basin: Tectonophysics, v. 266, p. 287-300, doi: 10.1016/S0040-1951(96)00194-1.

Horváth, F., and Royden, L., 1981, Mechanism for the formation of the intraCarpathian basins: A review: Earth Evolution Science, v. 3-4, p. 307-316.

Huismans, R.S., Podladchikov, Y.Y., and Cloething, S., 2001, Dynamic modelling of the transition from passive to active rifting, application to the Pannonian Basin: Tectonics, v. 20, p. 1021-1039, doi: 10.1029/2001TC900010.

Iwamori, H., 1998, Transportation of $\mathrm{H}_{2} \mathrm{O}$ and melting in subduction zones: Earth and Planetary Science Letters, v. 160, p. 65-80, doi: 10.1016/ S0012-821X(98)00080-6.

Jiříček, R., 1979, Tectonic development of the Carpathian arc in the Oligocene and Neogene, in Mahel, M., ed., Tectonic Profiles through the Western Carpathians: Bratislava, Geological Institute Dionyz Stur, p. 205-214.

Juvigne, E., Gewelt, M., Gilot, E., Hurtgen, C., Seghedi, I., Szakács, A., Gábris, G., Hadnagy, Á., and Horváth, E., 1994, Une eruption vieille d'environ 10700 ans $\left({ }^{14} \mathrm{C}\right)$ dans les Carpates orientales (Roumanie): Paris, Comptes Rendus Academie des Sciences, v. 318, p. 1233-1238.

Knapp, J.H., Knapp, C.C., Raileanu, V., Matenco, L., Mocanu, V., and Dinu, C., 2005 , Crustal constraints on the origin of mantle seismicity in the Vrancea zone, Romania: The case for active continental lithospheric delamination: Tectonophysics, v. 410, p. 311-323, doi: 10.1016/j.tecto.2005.02.020.

Kogiso, T., Hirschmann, M.M., and Reiners, P.W., 2004, Length scales of mantle heterogeneities and their relationship to ocean island basalt geochemistry: Geochimica et Cosmochimica Acta, v. 68, p. 345-360, doi: 10.1016/S0016-7037(03)00419-8.

Konečný, V., Lexa, J., Balogh, K., and Konečný, P., 1995, Alkali basalt volcanism in Southern Slovakia: Volcanic forms and time evolution, in Downes, H., and Vaselli, O., eds., Neogene and Related Magmatism in the Carpatho-Pannonian Region: Acta Volcanologica, v. 7, p. 167-171.

Konečný, V., Kováč, M., Lexa, J., and Šefara, J., 2002, Neogene evolution of the Carpatho-Pannonian region: An interplay of subduction and backarc diapiric uprise in the mantle: European Geophysical Union Stephan Mueller Special Publication Series, v. 1, p. 105-123.

Kostopoulos, D.K., and James, S.D., 1992, Parameterization of the melting regime of the shallow upper mantle and the effects of variable lithospheric stretching on mantle modal stratification and trace element concentrations in magmas: Journal of Petrology, v. 33, p. 665-691.

Kováč, M., Nagymarosy, A., Oszczypko, N., Slaczka, A., Csontos, L., Marunteanu, M., Matenco, L., and Márton, E., 1998, Palinspastic reconstruction of the Carpathian-Pannonian region during the Miocene, in Rakús, M., ed., Geodynamic Evolution of the Western Carpathians: Bratislava, Geological Survey of Slovak Republik, p. 189-217.

Le Bas, M.J., Le Maitre, R.W., Streckeisen, A., and Zanettin, B., 1986, A chemical classification of volcanic rocks based on the total alkali-silica diagram: Journal of Petrology, v. 27, p. 745-750.

Lenkey, L., Dövényi, P., Horváth, F., and Cloetingh, S., 2002, Geothermics of the Pannonian Basin and its bearing on the neotectonics: European Geophysical Union Stephan Mueller Special Publications Series, v. 3, p. $29-40$.

Lexa, J., and Konečný, V., 1974, The Carpathian volcanic arc: A discussion: Acta Geologica Hungarica, v. 18, p. 279-294.

Lexa, J., and Konečný, V., 1998, Geodynamic aspects of the Neogene to Quaternary volcanism, in Rakús, M., ed., Geodynamic Development of the Western Carpathians: Bratislava, Geological Survey of Slovak Republik, p. 219-240.

Lustrino, M., 2000, Phanerozoic geodynamic evolution of the circum-Italian realm: International Geology Review, v. 42, p. 724-757.

Macera, P., Gasperini, D., Piromallo, C., Blichert-Toft, J., Bosch, D., Del Moro, A., and Martin, S., 2003, Geodynamic implications of deep mantle upwelling in the source of Tertiary volcanics from the Veneto region (south-eastern Alps): Journal of Geodynamics, v. 36, p. 563-590, doi: 10.1016/j.jog.2003.08.004.

Márton, E., and Fodor, L., 2003, Tertiary paleomagnetic results and structural analysis from the Transdanubian Range (Hungary): Rotational disintegration of the Alcapa unit: Tectonophysics, v. 363, p. 201-224, doi: 10.1016/ S0040-1951(02)00672-8.

Mason, P.R.D., Downes, H., Seghedi, I., Szakács, A., and Thirlwall, M.F., 1995, Low-pressure evolution of magmas from the Calimani, Gurghiu and Harghita Mountains: East Carpathians: Acta Vulcanologica, v. 7, p. 43-52.

Mason, P.R.D., Downes, H., Thirlwall, M., Seghedi, I., Szakács, A., Lowry, D., and Mattey, D., 1996, Crustal assimilation as a major petrogenetic process in East Carpathian Neogene to Quaternary continental margin arc magmas: Journal of Petrology, v. 37, p. 927-959.

Mason, P.R.D., Seghedi, I., Szakacs, A., and Downes, H., 1998, Magmatic constraints on geodynamic models of subduction in the East Carpathians, Romania: Tectonophysics, v. 297, p. 157-176, doi: 10.1016/S0040-1951 (98)00167-X

McDonough, W.F., and Sun, S.S., 1995, The composition of the Earth: Chemical Geology, v. 120, p. 223-253, doi: 10.1016/0009-2541(94)00140-4.

McKenzie, D., 1978, Some remarks on the development of sedimentary basins: Earth and Planetary Science Letters, v. 40, p. 25-32.

McKenzie, D., 1989, Some remarks on the movement of small melt fractions in the mantle: Earth and Planetary Science Letters, v. 95, p. 53-72, doi: 10.1016/0012-821X(89)90167-2.

Meibom, A., and Anderson, D.L., 2004, The statistical upper mantle assemblage: Earth and Planetary Science Letters, v. 217, p. 123-139, doi: 10.1016/S0012-821X(03)00573-9.

Moriya, I., Okuno, M., Nakamura, T., Ono, K., Szakács, A., and Seghedi, I., 1996, Radiocarbon ages of charcoal fragments from the pumice flow deposits of the last eruption of Ciomadul volcano, Romania: Summary of Research using AMS at Nagoya University, v. 7, p. 255. 
Nemčok, M., and Lexa, J., 1990, Evolution of the Basin and Range structure around the Ziar Mountain Range: Geologica Carpathica, v. 41, p. 229258.

Nemčok, M., Pospisil, L., Lexa, J., and Donelick, R.A., 1998, Tertiary subduction and slab break-off model of the Carpathian-Pannonian region: Tectonophysics, v. 295, p. 307-340, doi: 10.1016/S0040-1951(98)00092-4.

Niu, Y., and O'Hara, M.J., 2003, Origin of ocean island basalts: Anew perspective from petrology, geochemistry, and mineral physics considerations: Journal of Geophysical Research, v. 108, 2209, doi: 10.1029/2002JB002048.

Oncescu, M.C., and Bonjer, K.-P., 1997, A note on the depth recurrence and strain release of large Vrancea earthquakes: Tectonophysics, v. 272, p. 291-302, doi: 10.1016/S0040-1951(96)00263-6.

Oncescu, M.C., Burlacu, V., Anghel, M., and Smalberger, V., 1984, Threedimensional P-wave velocity image under the Carpathian arc: Tectonophysics, v. 106, p. 305-319, doi: 10.1016/0040-1951(84)90182-3.

Panaiotu, C.G., Pécskay, Z., Hambach, U., Seghedi, I., Panaiotu, C.E., Tetsumaru, I., Orleanu, M., and Szakács, A., 2004, Short-lived Quaternary volcanism in the Persani Mountains (Romania) revealed by combined K-Ar and paleomagnetic data: Geologica Carpathica, v. 55, p. 333-339.

Patrascu, S., Bleahu, M., and Panaiotu, C., 1990, Tectonic implications of paleomagnetic research into Upper Cretaceous magmatic rocks in the Apuseni Mountains, Romania: Tectonophysics, v. 180, p. 309-322, doi: 10.1016/0040-1951(90)90316-Z.

Patrascu, S., Panaiotu, C., Seclaman, M., and Panaiotu, C.E., 1994, Timing of rotational motion of Apuseni Mountains (Romania): Paleomagnetic data from Tertiary magmatic rocks: Tectonophysics, v. 233, p. 163-176, doi: 10.1016/0040-1951(94)90239-9.

Pearce, J.A., and Peate, D.W., 1995, Tectonic implications of the composition of volcanic arc magmas: Annual Review of Earth and Planetary Sciences, v. 23, p. 251-285, doi: 10.1146/annurev.ea.23.050195.001343.

Peccerillo, A., 2003, Plio-Quaternary magmatism in Italy: Episodes, v. 26, p. 222-226.

Peccerillo, A., 2005, Plio-Quaternary volcanism in Italy: Petrology, geochemistry, geodynamics: Berlin-New York, Springer, $365 \mathrm{p}$.

Peccerillo, A., and Lustrino, M., 2005, Compositional variations of the PlioQuaternary magmatism in the circum-Tyrrhenian area: deep- versus shallow-mantle processes, in Foulger, G.R., et al., eds., Plates, Plumes, and Paradigms: Geological Society of America Special Paper 388, p. 421-434.

Pécskay, Z., Lexa, J., Szakács, A., Balogh, K., Seghedi, I., Konecny, V., Kovács, M., Márton, E., Kaliciak, M., Széky-Fux, V., Póka, T., Gyarmati, P., Edelstein, O., Rosu, E., and Zec, B., 1995a, Space and time distribution of Neogene-Quaternary volcanism in the Carpatho-Pannonian region, in Downes, H., and Vaselli, O., eds., Neogene and Related Magmatism in the Carpatho-Pannonian Region: Acta Vulcanologica, v. 7, p. 15-28.

Pécskay, Z., Edelstein, O., Seghedi, I., Szakacs, A., Kovacs, M., Crihan, M., and Bernad, A., 1995b, K-Ar datings of Neogene-Quaternary calc-alkaline volcanic rocks in Romania, in Downes, H., and Vaselli, O., eds., Neogene and Related Magmatism in the Carpatho-Pannonian Region: Acta Vulcanologica, v. 7, p. 53-61.

Peresson, H., and Decker, K., 1997, Far-field effects of late Miocene subduction in the Eastern Carpathians: E-W compression and inversion of structures in the Alpine-Carpathian-Pannonian region: Tectonics, v. 16, p. 38-56, doi: 10.1029/96TC02730.

Pilet, S., Hernandez, J., Sylvester, P., and Poujol, M., 2005, The metasomatic alternative for ocean island basalt chemical heterogeneity: Earth and Planetary Science Letters, v. 236, p. 148-166, doi: 10.1016/ j.epsl.2005.05.004

Piromallo, C., and Morelli, A., 2003, P-wave tomography of the mantle under the Alpine-Mediterranean area: Journal of Geophysical Research, v. 108, 2065, doi: 10.1029/2002JB001757.

Piromallo, C., Vincent, A.P., Yuen, D.A., and Morelli, A., 2001, Dynamics of the transition zone under Europe inferred from wavelet cross-spectra of seismic tomography: Physics of the Earth and Planetary Interiors, v. 125, p. 125-139, doi: 10.1016/S0031-9201(01)00249-7.

Popa, M., Radulian, M., Grecu, B., Popescu, E., and Placinta, A.O., 2005 , Attenuation in Southeastern Carpathians area: Result of upper mantle inhomogeneity: Tectonophysics, v. 410, p. 235-249, doi: $10.1016 /$ j.tecto.2004.12.037.

Prelevic, D., Cvetkovic, V., Foley, S.F., Jovanovic, M., and Melzer, S., 2001, Tertiary ultrapotassic-potassic rocks from Serbia, Yugoslavia: Acta Vulcanologica, v. 13, p. 101-115.

Prelevic, D., Foley, S.F., Romer, R.L., Cvetkovic, V., and Downes, H., 2005, Tertiary ultrapotassic volcanism in Serbia: Constraints on petrogenesis and mantle source characteristics: Journal of Petrology, v. 46, p. 14431487, doi: 10.1093/petrology/egi022.

Ratschbacher, L., Frisch, W., Linzer, H.-G., and Merle, O., 1991, Lateral extrusion in the eastern Alps, 2. Structural analysis: Tectonics, v. 10, p. 257-271.

Reiners, P.W., Hammond, P.E., McKenna, J.M., and Duncan, R.A., 2000, Young basalts of the central Washington Cascades, flux melting of the mantle, and trace element signatures of primary arc magmas: Contributions to Mineralogy and Petrology, v. 138, p. 249-264, doi: 10.1007 / s004100050561.

Rosenbaum, J.M., Wilson, M., and Downes, H., 1997, Multiple enrichment of the Carpathian-Pannonian mantle: $\mathrm{Pb}-\mathrm{Sr}-\mathrm{Nd}$ isotope and trace-element constraints: Journal of Geophysical Research, v. 102, p. 14947-14961.

Roure, F., Roca, E., and Sassi, W., 1993, The Neogene evolution of the outer Carpathian flysch units (Poland, Ukraine and Romania): Kinematics of a foreland/fold-and-thrust belt system: Sedimentary Geology, v. 86, p. 177201, doi: 10.1016/0037-0738(93)90139-V.

Royden, L.H., 1993, Evolution of retreating subduction boundaries formed during continental collision: Tectonics, v. 12, p. 629-638.

Royden, L.H., Horváth, F., and Burchfiel, B.C., 1982, Transform faulting, extension and subduction in the Carpathian-Pannonian region: Geological Society of America Bulletin, v. 93, p. 717-725, doi: 10.1130/00167606(1982) $93<717$ :TFEASI $>2.0$. CO;2.

Royden, L.H., Horváth, F., Nagymarosy, A., and Stegena, L., 1983, Evolution of the Pannonian Basin system. 2. Subsidence and thermal history: Tectonics, v. 2, p. 91-137.

Russo, R.M., Mocanu, V., Radulian, M., Popa, M., and Bonjer, K.-P., 2005, Seismic attenuation in the Carpathian bend zone and surroundings: Earth and Planetary Science Letters, v. 237, p. 695-709, doi: 10.1016/ j.eps1.2005.06.046.

Sachsenhofer, R.F., Lankreijer, A., Cloetingh, S., and Ebner, F., 1997, Subsidence analysis and quantitative basin modeling in the Styrian Basin (Pannonian Basin system, Austria): Tectonophysics, v. 272, p. 175-196, doi: 10.1016/S0040-1951(96)00257-0.

Sanders, C., 1998, Tectonics and erosion: Competitive forces in a compressive orogen: A fission track study of the Romanian Carpathians [Ph.D. thesis]: Amsterdam, The Netherlands, Vrije Universiteit, 204 p.

Sandulescu, M., 1988, Cenozoic tectonic history of the Carpathians, in Royden, L., and Horváth, F., eds., The Pannonian Basin: American Association of Petroleum Geologists (AAPG) Memoir 45, p. 17-26.

Seghedi, I., Balintoni, I., and Szakacs, A., 1998, Interplay of tectonics and Neogene post-collisional magmatism in the Intracarpathian region: Lithos, v. 45, p. 483-497, doi: 10.1016/S0024-4937(98)00046-2.

Seghedi, I., Downes, H., Pecskay, Z., Thirlwall, M.F., Szakacs, A., Prychodko, M., and Mattey, D., 2001, Magma genesis in a subduction-related postcollisional volcanic arc segment: The Ukrainian Carpathians: Lithos, v. 57, p. 237-262, doi: 10.1016/S0024-4937(01)00042-1.

Seghedi, I., Downes, H., Szakacs, A., Mason, P.R.D., Thirlwall, M.F., Rosu, E., Pecskay, Z., Marton, E., and Panaiotu, C., 2004a, Neogene-Quaternary magmatism and geodynamics in the Carpathian-Pannonian region: A synthesis: Lithos, v. 72, p. 117-146, doi: 10.1016/j.lithos.2003.08.006

Seghedi, I., Downes, H., Vaselli, O., Szakacs, A., Balogh, K., and Pecskay, Z., 2004b, Post-collisional Tertiary-Quaternary mafic alkalic magmatism in the Carpathian-Pannonian region: A review: Tectonophysics, v. 393, p. 43-62, doi: 10.1016/j.tecto.2004.07.051.

Seghedi, I., Downes, H., Harangi, S., Mason, P.R.D., and Pecskay, Z., 2005, Geochemical response of magmas to Neogene-Quaternary continental collision in the Carpathian-Pannonian region: A review: Tectonophysics, v. 410, p. 485-499, doi: 10.1016/j.tecto.2004.09.015.

Seyitoglu, G., Anderson, D., Nowell, G., and Scott, B., 1997, The evolution from Miocene potassic to Quaternary sodic magmatism in western Turkey: Implications for enrichment processes in the lithospheric mantle: Journal of Volcanology and Geothermal Research, v. 76, p. 127-147, doi: 10.1016/S0377-0273(96)00069-8.

Sigmarsson, O., Condomines, M., Morris, J.D., and Harmon, R.S., 1990, Uranium and ${ }^{10} \mathrm{Be}$ enrichments by fluids in Andean arc magmas: Nature, v. 346, p. 163-165, doi: 10.1038/346163a0.

Simon, L., and Halouzka, R., 1996, Pútikov Vrsok volcano-The youngest volcano in the Western Carpathians: Slovak Geological Magazine, v. 2, p. $103-123$

Smith, A.D., 2005, The streaky mantle alternative to mantle plume and its bearing on bulk earth geochemical evolution, in Foulger, G.R., Natland, J.H., Presnall, D.C., and Anderson, D.L., eds., Plates, Plumes and Paradigms: Geological Society of America Special Paper 388, p. 303-325. 
Spakman, W., 1990, Images of the upper mantle of central Europe and the Mediterranean: Terra Nova, v. 2, p. 542-553.

Sperner, B., Lorenz, F., Bonjer, K., Hettel, S., Muller, B., and Wenzel, F., 2001, Slab break-off-Abrupt cut or gradual detachment? New insights from the Vrancea region (SE Carpathians, Romania): Terra Nova, v. 13, p. 172-179, doi: 10.1046/j.1365-3121.2001.00335.x.

Sperner, B., Ratschbacher, L., and Nemčok, M., 2002, Interplay between subduction retreat and lateral extrusion: Tectonics of the Western Carpathians: Tectonics, v. 21, 1051, doi: 10.1029/2001TC901028.

Sperner, B., Ioane, D., and Lillie, R.J., 2004, Slab behaviour and its surface expression: New insights from gravity modelling in the SE-Carpathians: Tectonophysics, v. 382, p. 51-84, doi: 10.1016/j.tecto.2003.12.008.

Stolper, E., and Newman, S., 1994, The role of water in the petrogenesis of Mariana trough magmas: Earth and Planetary Science Letters, v. 121, p. 293-325, doi: 10.1016/0012-821X(94)90074-4

Sun, S.-S., and McDonough, W.F., 1989, Chemical and isotopic systematics of oceanic basalts: Implications for mantle composition and processes, in Saunders, A.D., and Norry, M.J., eds., Magmatism in the Ocean Basins: Geological Society of London Special Publication 42, p. 313-345.

Szabó, C., Harangi, S., and Csontos, L., 1992, Review of Neogene and Quaternary volcanism of the Carpathian-Pannonian region: Tectonophysics, v. 208, p. 243-256, doi: 10.1016/0040-1951(92)90347-9.

Szabó, C., Falus, G., Zajacz, Z., Kovács, I., and Bali, E., 2004, Composition and evolution of lithosphere beneath the Carpathian-Pannonian region: A review: Tectonophysics, v. 393, p. 119-137, doi: 10.1016/ j.tecto.2004.07.031.

Szakács, A., and Seghedi, I., 1995, The Călimani-Gurghiu-Hargita volcanic chain, East Carpathians, Romania: Volcanological features: Acta Volcanologica, v. 7, p. 145-153.

Szakács, A., Seghedi, I., and Pécskay, Z., 1993, Peculiarities of South Harghita Mts. as the terminal segment of the Carpathian Neogene to Quaternary volcanic chain: Revue Roumaine de Géologie Géophysique et Géographie, Géologie, v. 37, p. 21-37.

Széky-Fux, V., and Kozák, M., 1984, Deep-situated Neogene volcanism in the Nyírség: Bulletin of the Hungarian Geological Society, v. 114, p. 147-159 (in Hungarian with English abstract).

Sztanó, O., and Tari, G., 1993, Early Miocene basin evolution in northern Hungary: Tectonics and eustasy: Tectonophysics, v. 226, p. 485-502, doi: 10.1016/0040-1951(93)90134-6.

Tari, G., Dövényi, P., Horváth, F., Dunkl, I., Lenkey, L., Stefanescu, M., Szafián, P., and Tóth, T., 1999, Lithospheric structure of the Pannonian Basin derived from seismic, gravity and geothermal data, in Durand, B., Jolivet, L., Horváth, F., and Séranne, M., eds., The Mediterranean Basins: Tertiary Extension within the Alpine Orogen: Geological Society of London Special Publication 156, p. 215-250.

Tatsumi, Y., 2005, The subduction factory: How it operates in the evolving Earth: GSA Today, v. 15, no. 7, p. 4-10.

Tatsumi, Y., and Eggins, S., 1995, Subduction Zone Magmatism: Cambridge, Massachusetts, Blackwell Science, $211 \mathrm{p}$.

Thompson, R.N., Leat, P.T., Dickin, A.P., Morrison, M.A., Hendry, G.L., and Gibson, S.A., 1990, Strongly potassic mafic magmas from litho- spheric mantle sources during continental extension and heating: Evidence from Miocene minettes of northwest Colorado, U.S.A.: Earth and Planetary Science Letters, v. 98, p. 139-153, doi: 10.1016/0012821X(90)90055-3.

Tomek, C., and Hall, J., 1993, Subducted continental margin imaged in the Carpathians of Czechoslovakia: Geology, v. 21, p. 535-538, doi: 10.1130/0091-7613(1993)021<0535:SCMIIN>2.3.CO;2.

Vaselli, O., Downes, H., Thirlwall, M.F., Dobosi, G., Coradossi, N., Seghedi, I., Szakács, A., and Vannucci, R., 1995, Ultramafic xenoliths in PlioPleistocene alkali basalts from the Eastern Transylvanian Basin: Depleted mantle enriched by vein metasomatism: Journal of Petrology, v. 36, p. $23-53$.

Vinkler, A.P., Harangi, S., Ntaflos, T., and Szakács, A., 2007, A Csomád vulkán (Keleti Kárpátok) horzsaköveinek kőzettani és geokémiai vizsgálatapetrogenetikai következtetések. [Petrology and geochemistry of the pumices from the Ciomadul volcano (Eastern Carpathians) - implications for the petrogenetic processes]: Földtani Közlöny (in press).

Wenzel, F., Lorenz, F., Sperner, B., and Oncescu, M.C., 1998, Seismotectonics of the Romanian Vrancea area, in Wenzel, F.E.A., ed., Vrancea Earthquakes: Dordrecht, Kluwer, p. 15-25.

Wenzel, F., Sperner, B., Lorenz, F., and Mocanu, V., 2002, Geodynamics, tomographic images and seismicity of the Vrancea region (SE-Carpathians, Romania): European Geophysical Union Stephan Mueller Special Publications Series, v. 3, p. 95-104.

Wilson, M., 1993, Magmatism and the geodynamics of basin formation: Sedimentary Geology, v. 86, p. 5-29, doi: 10.1016/0037-0738(93)90131-N.

Wilson, M., and Bianchini, G., 1999, Tertiary-Quaternary magmatism within the Mediterranean and surrounding regions, in Durand, B., Jolivet, L., Horváth, F., and Séranne, M., eds., The Mediterranean Basins: Tertiary Extension within the Alpine Orogen: Geological Society of London Special Publication 156, p. 141-168.

Wilson, M., and Downes, H., 1991, Tertiary-Quaternary extension-related alkaline magmatism in Western and Central Europe: Journal of Petrology, v. 32, p. $811-849$.

Wilson, M., and Patterson, R., 2001, Intraplate magmatism related to shortwavelength convective instabilities in the upper mantle: Evidence from the Tertiary-Quaternary volcanic province of western and central Europe, in Ernst, R.E., and Buchan, K.L., eds., Mantle Plumes: Their Identification through Time: Geological Society of America Special Paper 352, p. $37-58$.

Wilson, M., Tankut, A., and Güleç, N., 1997, Tertiary volcanism of the Galatia Province, Central Anatolia, Turkey: Lithos, v. 42, p. 105-121, doi: 10.1016/S0024-4937(97)00039-X.

Wortel, M.J.R., and Spakman, W., 2000, Subduction and slab detachment in the Mediterranean-Carpathian region: Science, v. 290, p. 1910-1917, doi: 10.1126/science. 290.5498 .1910

Zindler, A., and Hart, S.R., 1986, Chemical geodynamics: Annual Review of Earth and Planetary Sciences, v. 14, p. 493-571, doi: 10.1146/annurev. ea.14.050186.002425.

Manuscript Accepted by the Society 9 June 2006 